\title{
Highly Selective and Sensitive Dual Channel Schiff Base Chemosesnsors for the Detection of $\mathrm{Al}(\mathrm{III}), \mathrm{Fe}(\mathrm{III}) \& \mathrm{Cu}(\mathrm{II})$
}

\author{
By Santhi Sambamoorthy* \\ Amala Subbiah ${ }^{\dagger}$
}

Two Schiff bases derived from 2,4-dihydroxy acetophenone were synthesised and characterized by IR, UV-Vis, IH NMR, Mass spectral studies and single crystal X-ray diffraction studies. They were grown into a single crystal in 1:1 ethanol acetonitrile medium by slow evaporation technique and belong to monoclinic crystal system with P21/c space group. Hirshfeld surface analysis based on DFT method with 3-21G as basis set was used to calculate various intermolecular interactions. Finger print plots were made to find out the percentage of different types of interactions. The cation recognizing profile of the Schiff base receptors were explored by UV-Vis and fluorescence methods. The receptor 1 NMEPDHAPI was found to recognize Al3+and the receptor 2 NMPDHAPIwas found to recognize Fe3+and Cu2+ions selectively over a panel of other metal ions such as $\mathrm{Na}+, \mathrm{Mg} 2+, \mathrm{Ca} 2+, \mathrm{Mn} 2+, \mathrm{Co} 2+, \mathrm{Ni2}+, \mathrm{Zn} 2+, \mathrm{Sr} 2+, \mathrm{Cd} 2+, \mathrm{Ba} 2+$, $\mathrm{Hg} 2+$ and $\mathrm{Pb2}+$. The stoichiometry ratio of the receptors with $\mathrm{Al3}+$ and $\mathrm{Fe} 3+\& \mathrm{Cu} 2+$ obtained by the Job's plot was 2:1. The binding constant of the receptor 1 for Al3+was $10.11 \times 103$ and that ofreceptor 2 for $\mathrm{Fe} 3+$ and $\mathrm{Cu} 2+$ were $1.43 \times 10+2$ and $1.65 \times 10+2$ respectively. The detection limits for $\mathrm{Al3}+, \mathrm{Fe} 3+$ and $\mathrm{Cu} 2+$ were $6.5318 \times 10-9 \mathrm{M}, 1.265$ $X 10-6 M$ and $4.086 X 10-6 M$ respectively.

Keywords: Cation recognition, Chemosensor, Deformation density, Fluorescence Schiff base.

\section{Introduction and Literature Review}

Luminescence compounds are attracting much current research interest because of their wide applications including emitting materials for organic light emitting diodes, light harvesting materials for photo catalysis and fluorescent sensors for organic or inorganic analyses. Further, luminiscent metal complexes are a fascinating class of molecules that have found applications in many areas such as light emitting devices (LED) (Keyes et al., 2004).

Various transition metal ions are crucial for the life of living organism. Copper is an essential trace element present in all living systems and is important for the function of many cellular enzymes. However, $\mathrm{Cu}^{2+}$ can be toxic to biological systems when levels of $\mathrm{Cu}^{2+}$ ions exceed cellular needs and it is also capable of displacing other metal ions which act as cofactor in enzyme catalyzed reaction. Iron is one of the most important elements among heavy metals for metabolic processes, being indispensable for plants and animals and

*Associate Professor, Seethalakshmi Ramaswami College, India.

${ }^{\dagger}$ Lecturer, Seethalakshmi Ramaswami College, India. 
therefore it is essentially distributed in environmental and biological materials. For instance, in heamoglobin the metal center is iron and for vitamin $\mathrm{B}_{12}$ it is cobalt. In the Earth's crust, aluminium is the most abundant ( $8.3 \%$ by mass) metallic element and the third most abundant of all elements (after oxygen and silicon). The element aluminium is intertwined with our day-to-day activities. The wider use of the said metal in kitchen wares, soft drink cans, in pharmaceutical industry and also in food packing materials has exposed us to aluminium absorption resulting in slow accumulation of aluminium in various human organs leading to skeletal mineralization. The augmentation of aluminium in human bodies retards numerous enzyme activities thereby hampering iron metabolism. Besides, aluminum affects the lives of aquatic animals such as fish and invertebrates by causing osmoregulatory failure in them. Nerve fibre degeneration also can be ascribed to the adverse effect of aluminium where memory process gets affected, leading to the Alzheimer's and Parkinson's diseases (Shrivastava, 2012).

In recent years synthesis of Schiff base chemosensors finds much attention (Wang et al., 2010a; Yang et al., 2013; An et al., 2013; Wang et al., 2013). But Schiff bases for the detection of $\mathrm{Al}$ (III) is very less (Fan et al., 2014; Kim et al., 2012; Chang et al., 2014), we tried for synthesise a simple, easily preparable Schiff base chemosensors one with a speciality of single metal detection and another with the feature of multi ion detection which may further be used for the construction of logic gates (Wang et al., 2010a; Sahoo et al., 2016).

\section{Methodology}

All chemicals and solvents were of the analytical grade. All metals $(\mathrm{Cu}$, $\mathrm{Ni}, \mathrm{Fe}, \mathrm{Co}, \mathrm{Ca}, \mathrm{Mg}, \mathrm{Mn}, \mathrm{Zn}, \mathrm{Sr}, \mathrm{Na}, \mathrm{Ba}, \mathrm{Cd}, \mathrm{Hg}, \mathrm{Al}$ ) were used in the form of their chloride (sigma Aldrich) except $\mathrm{Pb}$, which was used as lead acetate.

\section{Synthesis and Characterization of Schiff Base Receptors}

N-4-methylphenyl (2,4-dihydroxy acetophenylideneimine), Receptor 1 (NMEPDHAPI) was synthesized by refluxing a mixture of ethanolic solutions of 2,4-dihydroxy acetophenone $(1 \mathrm{mmol})$ and anisidine $(1 \mathrm{mmol})$ for three hours. The solid obtained was filtered, washed with ether and recrystallized from 1:1 mixture of ethanol and acetonitrile. Yield 95\%, m.pt. $108^{\circ} \mathrm{C}$.

\section{FT-IR Spectra (Figure 1)}

In the case of NMEPDHAPI, the absorption band at $3479.77 \mathrm{~cm}^{-1}$ indicates the presence of phenolic $-\mathrm{OH}$ group involved in intramolecular hydrogen bonding (Aazam et al., 2006). There is a sharp and strong absorption band at $788.07 \mathrm{~cm}^{-1}$, corresponding to aromatic $\mathrm{C}-\mathrm{H}$ bending mode, which extends support to the view that the compound is aromatic (Issa et al., 2008). The 
presence of imine group $(-\mathrm{C}=\mathrm{N}-$ is confirmed by the strong band at $1605.07 \mathrm{~cm}^{-1}$ (Santhi et al., 2014).

Figure 1. IR Spectra of NMEPDHAPI

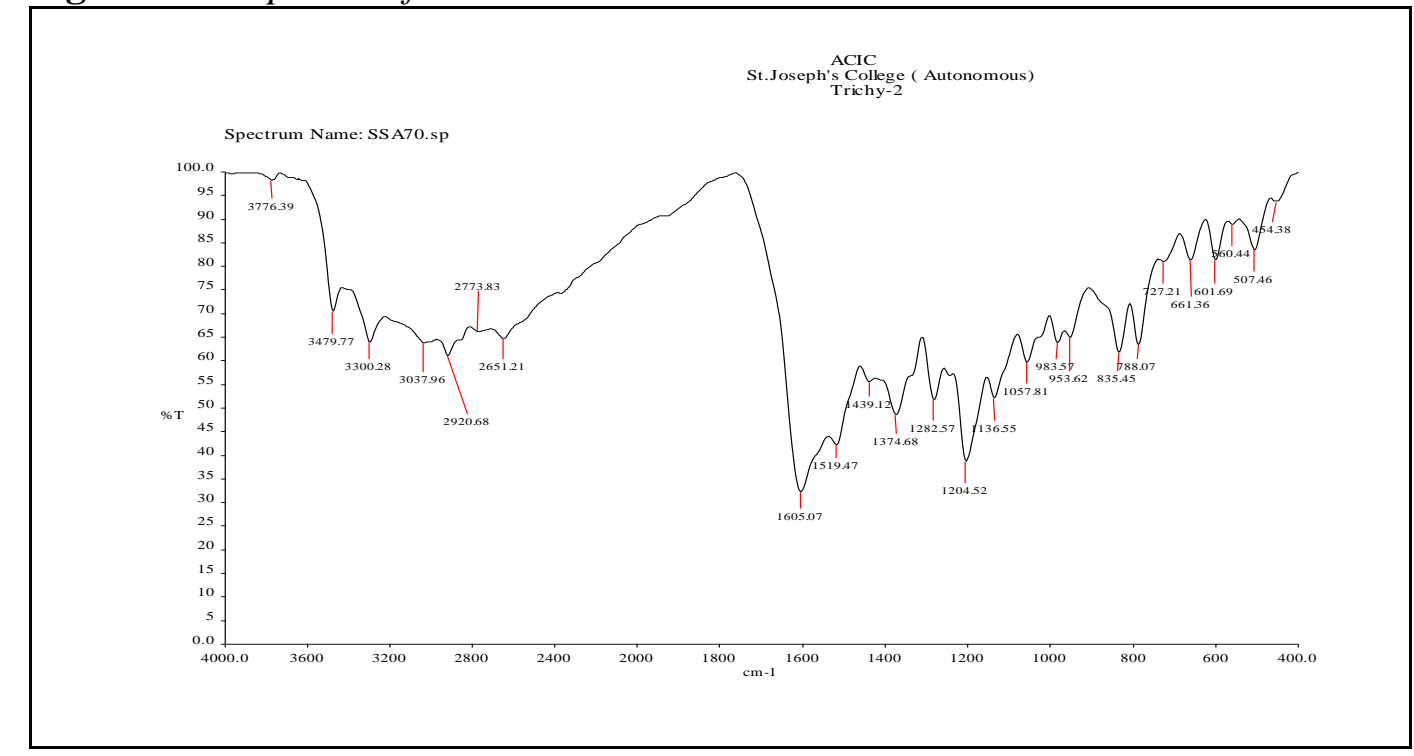

\section{$\underline{{ }^{1} \mathrm{H} \text { NMR Spectra (Figure 2) }}$}

The multiplet which extends from $\delta 6.37$ to $7.64 \mathrm{ppm}$ is due to the aromatic ring protons of the Schiff base ligand (Lashanizadegan and Seraj, 2010). The phenolic protons appear at $\delta 12.72 \mathrm{ppm}$ (Selvameena et al., 2014). The methyl protons appear at $\delta 2.39 \mathrm{ppm}$ and $\delta 2.93 \mathrm{ppm}$ (Aazam, 2010).

Figure 2. ${ }^{1} H$ NMR Spectra of NMEPDHAPI

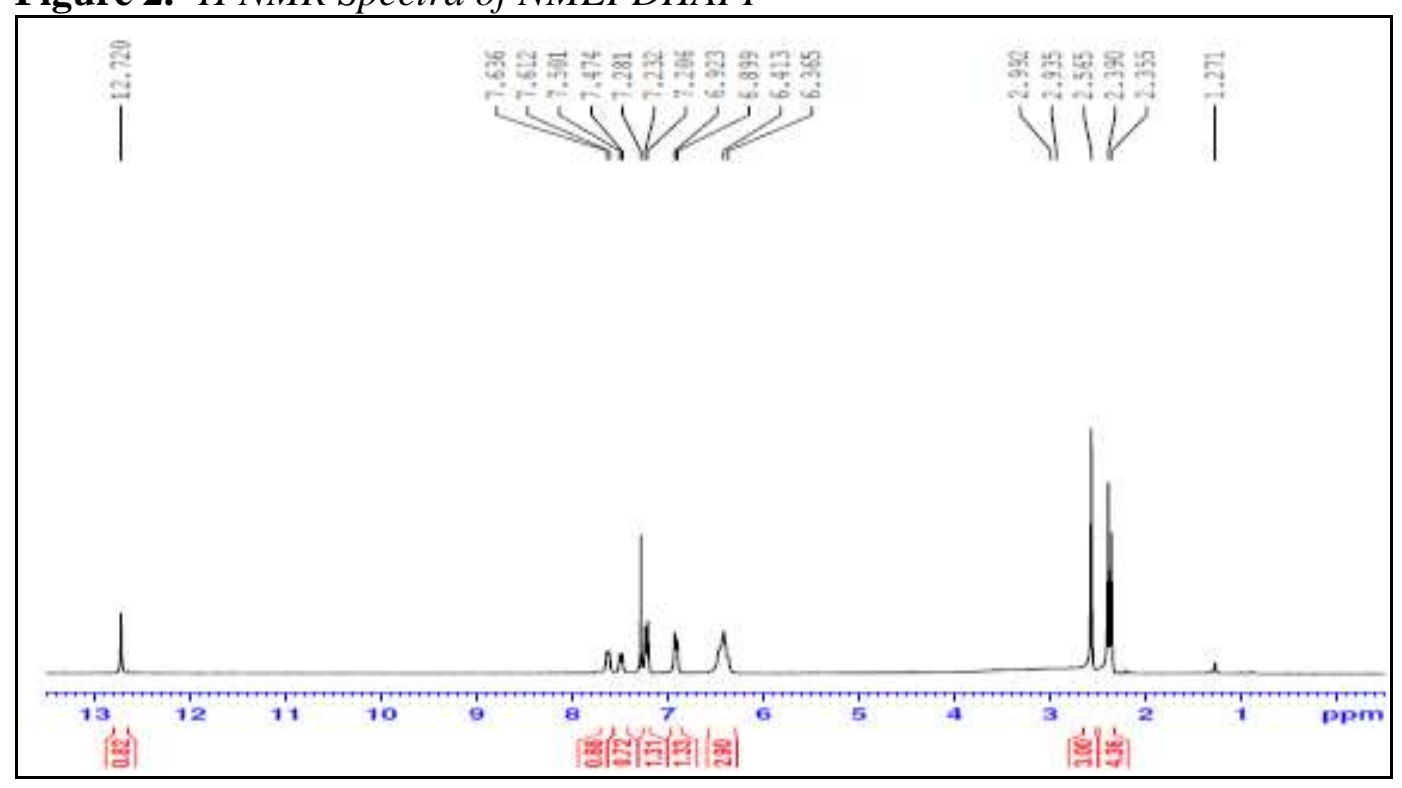




\section{$\underline{\text { Mass Spectra (Figure 3) }}$}

The electron impact mass of the ligand NMEPDHAPI confirms the proposed formula by showing a peak at $\mathrm{m} / \mathrm{z}=259.29$ corresponding to ligand moiety. This molecular ion peak is in good agreement with the suggested molecular formula $\left(\mathrm{C}_{15} \mathrm{H}_{17} \mathrm{O}_{3} \mathrm{~N}\right)(\mathrm{Kemp}, 2009)$.

Figure 3.Mass Spectra of NMEPDHAPI

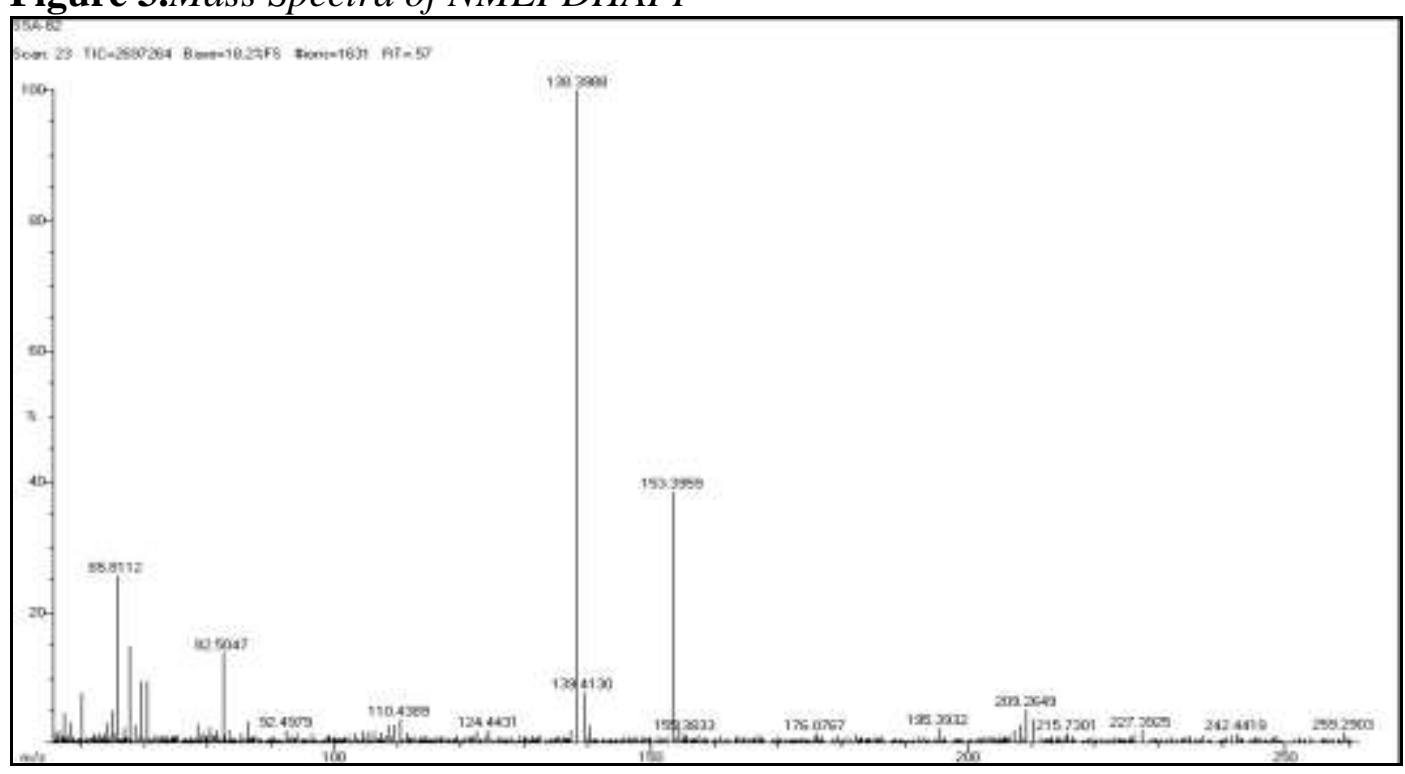

Description of Crystal Structure

The single crystal X-ray diffraction studies on the ligand further confirm the proposed structure. An ORTEP view of the ligand with atom-numbering scheme is shown in the Figure 4. The crystallographic data is shown in Table 1 and the bond angles and bond distances shown in Table 2. The existence of hydrogen bond between the phenolic hydrogen and azomethine nitrogen is confirmed and the data for the hydrogen bonding is presented in Table 3.A crystal with dimension of $0.400 \times 0.400 \times 0.300 \mathrm{~mm}^{3}$ was used for X-ray data collection. All the nonhydrogen atoms are refined anisotropically. All hydrogen atoms have been geometrically fixed and refined with isotropic thermal parameters. The asymmetric unit contains a molecule of Schiff base. The compound crystallizes in monoclinic lattice having $\mathrm{P} 2{ }_{1} / \mathrm{c}$ space group with $\mathrm{a}=8.9228(4) \AA, \mathrm{b}=8.2163(2)$ $\AA, c=18.5121(10) \AA, \alpha=\gamma=90^{\circ}, \beta=96.873(2)^{\circ}$ and $\mathrm{Z}=4$. The torsion angle between $\mathrm{C}(6)-\mathrm{C}(7)-\mathrm{N}(1)-\mathrm{C}(8)$ is $179.9(2)^{\circ}$, confirming the Schiff base formation. The C(7)-N(1) distance of 1.304(3) $\AA$ is normal double bond value and agrees well with those observed in compounds containing azomethine group. In the Schiff base ligand $\mathrm{C}(7)-\mathrm{N}(1)-\mathrm{C}(8)$ bond angle is $126.8(2)^{\circ}$. 
Table 1. Crystal Data and Structure Refinement for NMEPDHAPI

Identification code
CCDC Number
Empirical formula
Formula weight
Temperature
Wavelength
Crystal system
Space group
Unit cell dimensions

Volume

Z

Density (calculated)

Absorption coefficient

$\mathrm{F}(000)$

Crystal size

Theta range for data collection

Index ranges

Reflections collected

Independent reflections

Completeness to theta $=24.997^{\circ}$

Absorption correction

Max. and min. transmission

Refinement method

Data / restraints / parameters

Goodness-of-fit on $\mathrm{F}^{2}$

Final $\mathrm{R}$ indices [I $>2 \operatorname{sigma}(\mathrm{I})]$

$\mathrm{R}$ indices (all data)

Extinction coefficient

Largest diff. peak and hole
SSA77

1485803

C15 H17 N O3

259.29

293(2) K

$0.71073 \AA$

Monoclinic

$\mathrm{P} 21 / \mathrm{c}$

$\mathrm{a}=8.9228(4) \AA \quad \mathrm{a}=90^{\circ}$.

$\mathrm{b}=8.2163(4) \AA \quad \mathrm{b}=96.873(2)^{\circ}$.

$\mathrm{c}=18.5121(9) \AA \mathrm{g}=90^{\circ}$.

1347.41(11) $\AA^{3}$

4

$1.278 \mathrm{Mg} / \mathrm{m}^{3}$

$0.089 \mathrm{~mm}^{-1}$

552

$0.400 \times 0.400 \times 0.300 \mathrm{~mm}^{3}$

2.216 to $24.997^{\circ}$.

$-10<=\mathrm{h}<=10,-9<=\mathrm{k}<=9,-22<=\mathrm{l}<=22$

18813

$2382[\mathrm{R}(\mathrm{int})=0.0272]$

$99.9 \%$

Semi-empirical from equivalents

0.96 and 0.92

Full-matrix least-squares on $\mathrm{F}^{2}$

2382 / 0 / 190

1.092

$\mathrm{R} 1=0.0551, \mathrm{wR} 2=0.1371$

$\mathrm{R} 1=0.0772, \mathrm{wR} 2=0.1649$

$\mathrm{n} / \mathrm{a}$

0.229 and -0.231 e. $\AA^{-3}$

N-4-methoxylpheny(2,4-dihydroxy acetophenylideneimine), Receptor 2 (NMPDHAPI) was synthesized by refluxing a mixture of ethanolic solutions of 2,4-dihydroxy acetophenone $(1 \mathrm{mmol})$ and toluidine $(1 \mathrm{mmol})$ for three hours. The solid obtained was filtered, washed with ether and recrystallized from 1:1 mixture of ethanol and acetonitrile. Yield 95\%, m.pt. $250{ }^{\circ} \mathrm{C}$. 


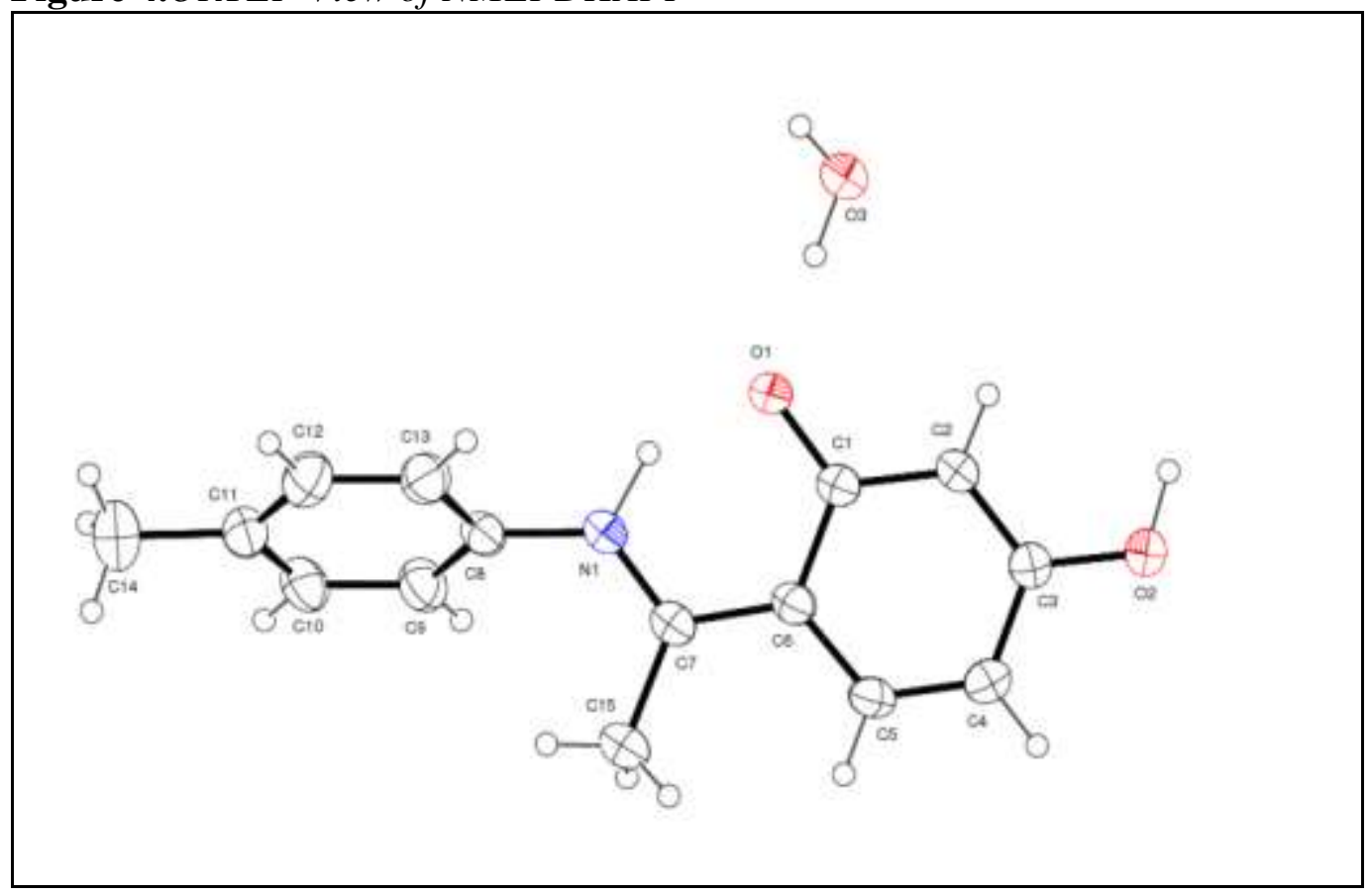

Table 2. Selected Bond Distances $(\AA)$ and Bond Angles $\left({ }^{\circ}\right)$ for NMEPDHAP

$\begin{array}{llll}\mathrm{C}(1)-\mathrm{O}(1) & 1.305(3) & \mathrm{N}(1)-\mathrm{C}(7)-\mathrm{C}(6) & 118.4(2) \\ \mathrm{C}(3)-\mathrm{O}(2) & 1.358(3) & \mathrm{N}(1)-\mathrm{C}(7)-\mathrm{C}(15) & 120.3(2) \\ \mathrm{C}(7)-\mathrm{N}(1) & 1.304(3) & \mathrm{C}(9)-\mathrm{C}(8)-\mathrm{N}(1) & 121.8(2) \\ \mathrm{C}(8)-\mathrm{N}(1) & 1.424(3) & \mathrm{C}(13)-\mathrm{C}(8)-\mathrm{N}(1) & 118.4(2) \\ \mathrm{N}(1)-\mathrm{H}(1 \mathrm{~A}) & 1.03(3) & \mathrm{C}(7)-\mathrm{N}(1)-\mathrm{C}(8) & 126.8(2) \\ \mathrm{O}(2)-\mathrm{H}(2 \mathrm{~A}) & 0.97(4) & \mathrm{C}(7)-\mathrm{N}(1)-\mathrm{H}(1 \mathrm{~A}) & 113(2) \\ & & \mathrm{C}(8)-\mathrm{N}(1)-\mathrm{H}(1 \mathrm{~A}) & 120(2)\end{array}$

Table 3. Hydrogen Bonds for NMEPDHAPI [ $\AA$ and ${ }^{\circ}$ ]

\begin{tabular}{lcccc} 
D-H...A & $\mathrm{d}(\mathrm{D}-\mathrm{H})$ & $\mathrm{d}(\mathrm{H} \ldots \mathrm{A})$ & $\mathrm{d}(\mathrm{D} \ldots \mathrm{A})$ & $<(\mathrm{DHA})$ \\
\hline $\mathrm{N}(1)-\mathrm{H}(1 \mathrm{~A}) \ldots \mathrm{O}(1)$ & $1.03(3)$ & $1.58(3)$ & $2.495(2)$ & $145(3)$ \\
$\mathrm{O}(3)-\mathrm{H}(4 \mathrm{~A}) \ldots \mathrm{O}(2) \# 2$ & $0.85(4)$ & $2.06(4)$ & $2.909(3)$ & $175(3)$ \\
$\mathrm{O}(2)-\mathrm{H}(2 \mathrm{~A}) \ldots \mathrm{O}(3) \# 1$ & $0.97(4)$ & $1.66(4)$ & $2.625(3)$ & $174(3)$ \\
$\mathrm{N}(1)-\mathrm{H}(1 \mathrm{~A}) \ldots \mathrm{O}(1)$ & $1.03(3)$ & $1.58(3)$ & $2.495(2)$ & $145(3)$ \\
$\mathrm{O}(3)-\mathrm{H}(4 \mathrm{~A}) \ldots \mathrm{O}(2) \# 2$ & $0.85(4)$ & $2.06(4)$ & $2.909(3)$ & $175(3)$
\end{tabular}

Symmetry transformations used to generate equivalent atoms:

\#1-x+1,y-1/2,-z+5/2 \#2 x,y+1,z

FT-IR Spectra (Figure 5)

In the case of NMPDHAPI the absorption band at $3431.96 \mathrm{~cm}^{-1}$ indicates the presence of phenolic - $\mathrm{OH}$ group involved in intramolecular hydrogen bonding 
(Aaazam et al., 2006). There is sharp and strong absorption band at $774.05 \mathrm{~cm}^{-}$ ${ }^{1}$, corresponding to aromatic $\mathrm{C}-\mathrm{H}$ bending mode, which extends support to the view that the compound is aromatic (Issa et al., 2008). The presence of imine group $\left(-\mathrm{C}=\mathrm{N}-\right.$ is confirmed by the strong band at $1587.73 \mathrm{~cm}^{-1}$ (Santhi et al., 2014).

Figure 5. IR Spectra of NMPDHAPI

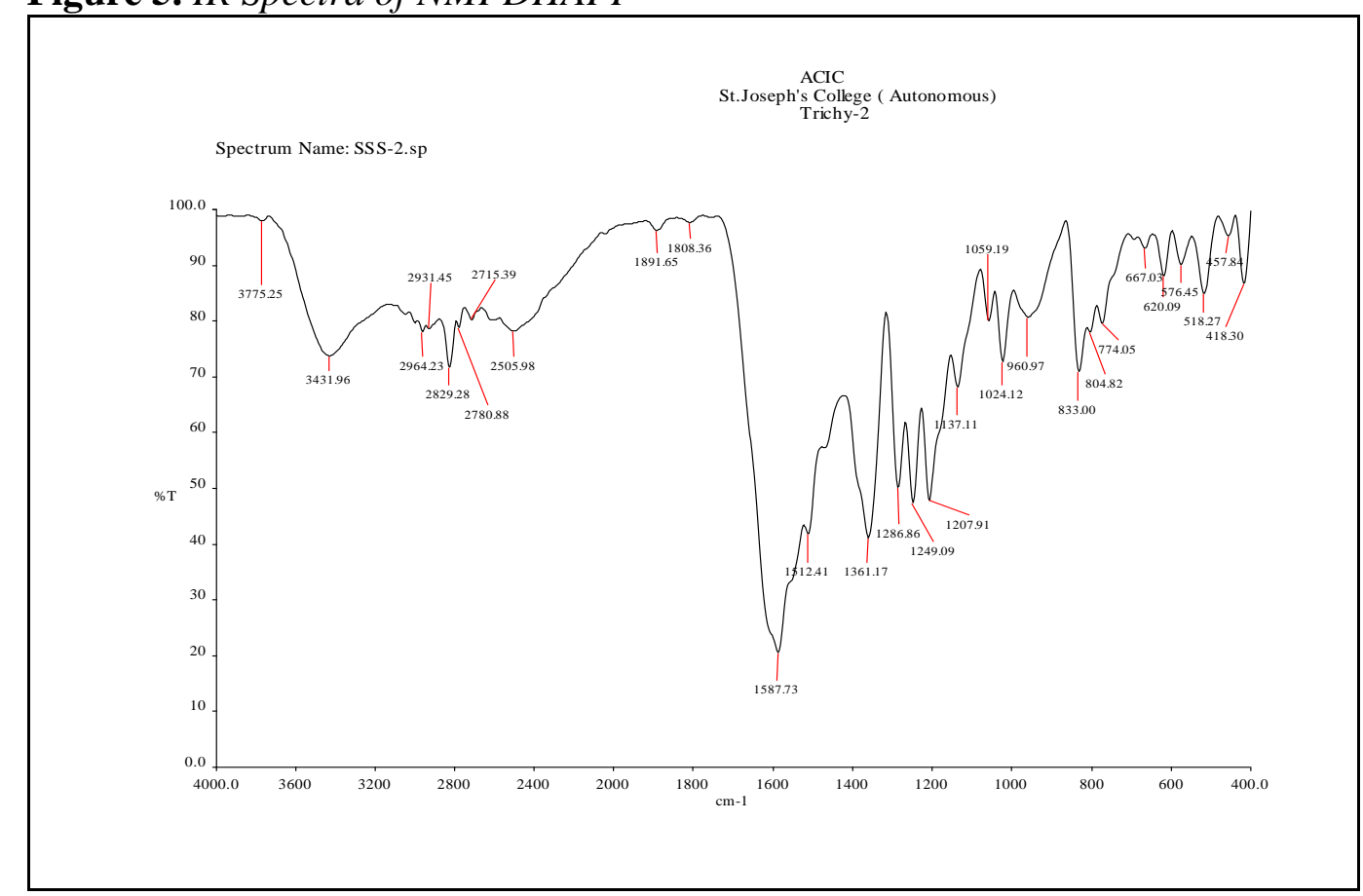

\section{${ }^{1}$ H NMR Spectra (Figure 6)}

The multiplet which extends from $\delta 6.21$ to $7.56 \mathrm{ppm}$ is due to the aromatic ring protons of the Schiff base ligand (Santhi et al., 2014). The phenolic protons at ortho position of the azomethine group appear at $\delta 10.07 \mathrm{ppm}$ (Selvameena et al., 2014). The phenolic proton at para position of the azomethine group appears as singlet at $\delta 15.39 \mathrm{ppm}$. The methyl protons appear at $\delta 2.50 \mathrm{ppm}$ (Aazam, 2010). The methoxy protons appear at $\delta 3.75 \mathrm{ppm}$. 
Vol. 5, No. 2 Sambamoorthy et al.: Highly Selective and Sensitive Dual Channel...

Figure 6. ${ }^{1} H$ NMR Spectra of NMPDHAPI

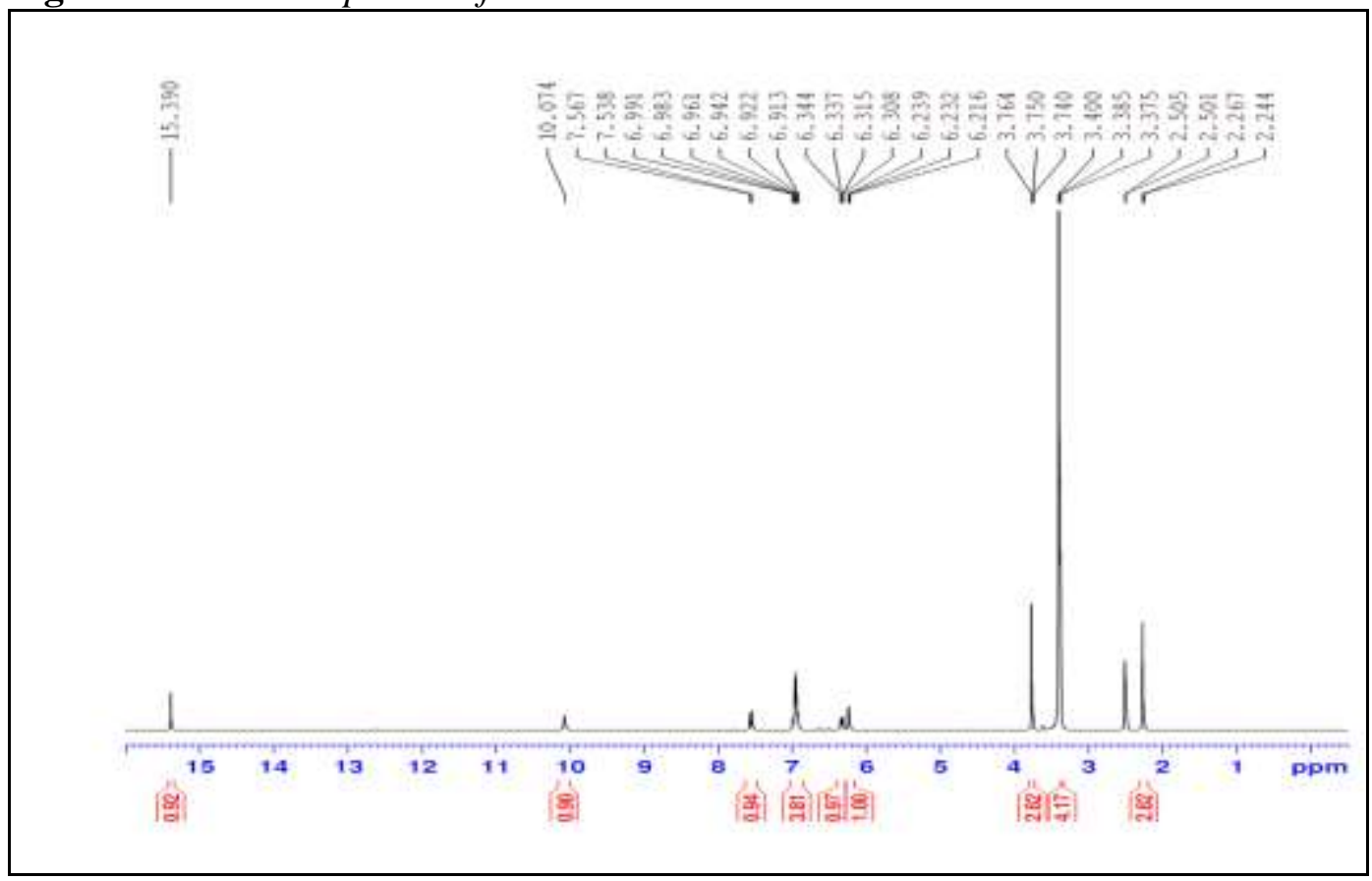

\section{Mass Spectra (Figure 7)}

The electron impact mass of the ligand NMPDHAPI confirms the proposed formula by showing a peak at $\mathrm{m} / \mathrm{z}=257.00$ corresponding to ligand moiety. This molecular ion peak is in good agreement with the suggested molecular formula $\left(\mathrm{C}_{15} \mathrm{H}_{15} \mathrm{O}_{3} \mathrm{~N}\right)$ (Kemp, 2009).

Figure 7.Mass Spectra of NMPDHAPI

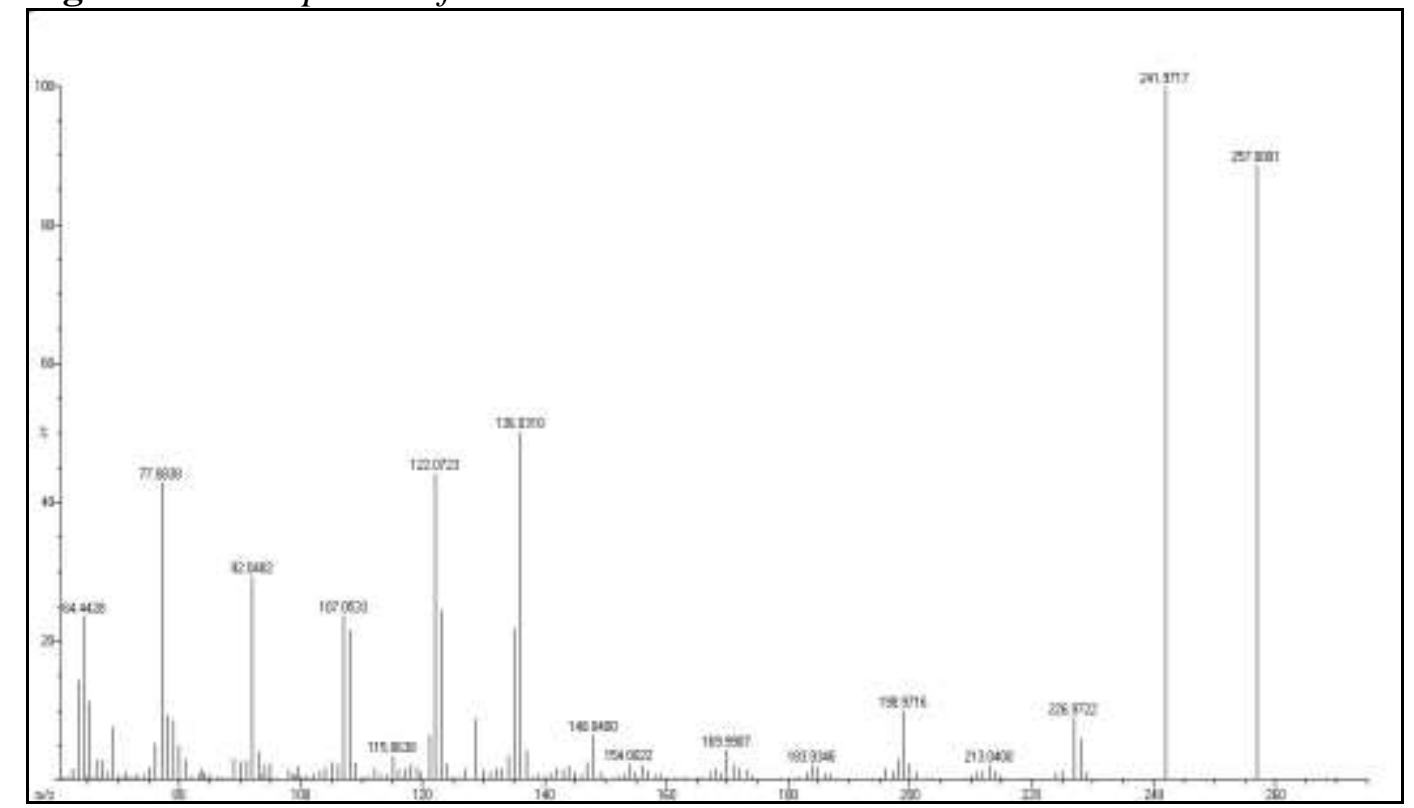




\section{Description of Crystal Structure of Ligand NMPDHAPI}

Figure 8.ORTEP View of NMPDHAPI

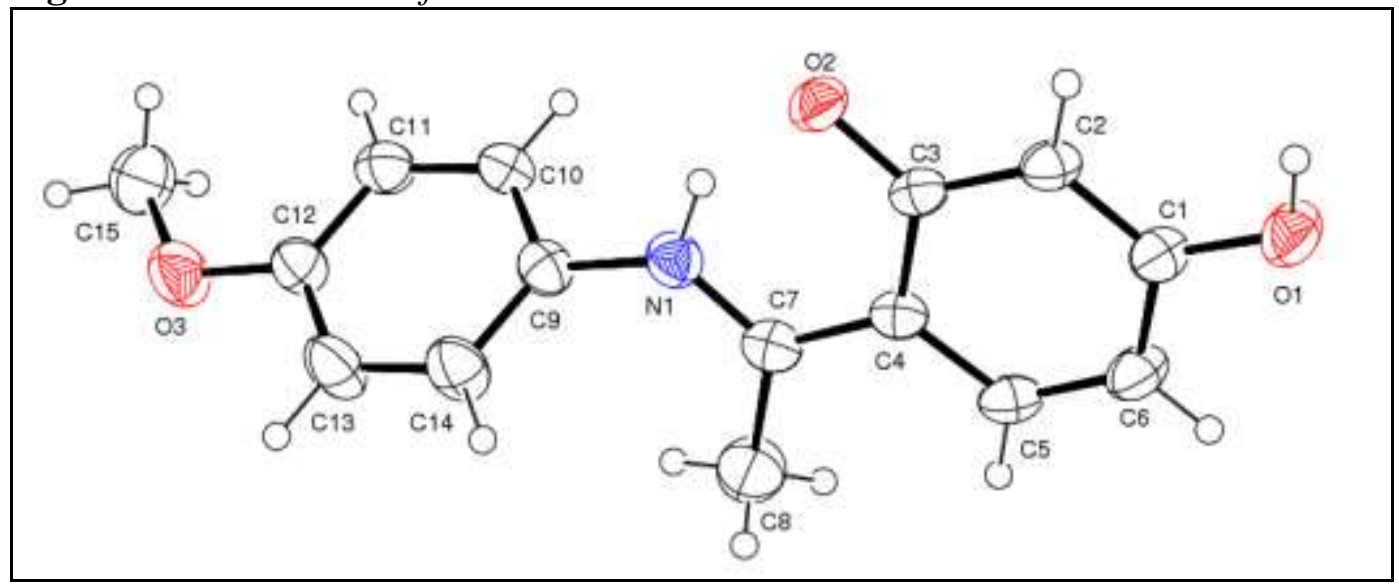

Table 4. Crystal Data and Structure Refinement for NMPDHAPI

\section{Identification code}

CCDC number

Empirical formula

Formula weight

Temperature

Wavelength

Crystal system

Space group

Unit cell dimensions

Volume

Z

Density (calculated)

Absorption coefficient

$\mathrm{F}(000)$

Crystal size

Theta range for data collection

Index ranges

Reflections collected

Independent reflections

Completeness to theta $=24.998^{\circ}$

Absorption correction

Max. and min. transmission

Refinement method

Data / restraints / parameters

Goodness-of-fit on $\mathrm{F}^{2}$

Final $\mathrm{R}$ indices [I $>2 \operatorname{sigma}(\mathrm{I})]$

$\mathrm{R}$ indices (all data)

Extinction coefficient

Largest diff. peak and hole
SANTHIA

1429533

C15 H15 N O3

257.28

296(2) K

$0.71073 \AA$

Monoclinic

$\mathrm{P} 2 / \mathrm{c}$

$\mathrm{a}=9.0009(4) \AA \quad \alpha=90^{\circ}$.

$\mathrm{b}=6.7248(2) \AA \quad \beta=99.450(2)^{\circ}$.

$\mathrm{c}=21.8564(10) \AA \gamma=90^{\circ}$.

1305.00(9) $\AA^{3}$

4

$1.309 \mathrm{Mg} / \mathrm{m}^{3}$

$0.092 \mathrm{~mm}^{-1}$

544

$0.300 \times 0.250 \times 0.200 \mathrm{~mm}^{3}$

2.294 to $24.998^{\circ}$.

$-10<=\mathrm{h}<=10,-7<=\mathrm{k}<=7,-25<=1<=25$

14379

$2291[\mathrm{R}($ int $)=0.0239]$

$100.0 \%$

Semi-empirical from equivalents

0.991 and 0.975

Full-matrix least-squares on $\mathrm{F}^{2}$

2291 / 0 / 179

1.035

$\mathrm{R} 1=0.0356, \mathrm{wR} 2=0.0905$

$\mathrm{R} 1=0.0475, \mathrm{wR} 2=0.1012$

$0.018(2)$

0.173 and -0.135 e. $\AA^{-3}$ 
The single crystal X-ray diffraction studies on the ligand further confirm the proposed structure. An ORTEP view of the ligand with atom-numbering scheme is shown in Figure 8. The crystallographic data is shown in Table 4 and the bond angles and bond distances shown in Table 5. The existence of hydrogen bond between the phenolic hydrogen and azomethine nitrogen is confirmed and the data for the hydrogen bonding is presented in Table 6 . The existence of hydrogen bond between the phenolic hydrogen and azomethine nitrogen is confirmed. A crystal with dimension of $0.300 \times 0.250 \times 0.200 \mathrm{~mm}^{3}$ was used for X-ray data collection. All the non-hydrogen atoms are refined anisotropically. All hydrogen atoms have been geometrically fixed and refined with isotropic thermal parameters. The asymmetric unit contains a molecule of Schiff base. The compound crystallizes in monoclinic lattice having $\mathrm{P} 2{ }_{1} / \mathrm{c}$ space group with $\mathrm{a}=9.0009(4) \AA, \mathrm{b}=6.7248(2) \AA, \mathrm{c}=21.8564(10) \AA, \alpha=\gamma=$ $90^{\circ}, \beta=99.450(2)^{\circ}$ and $\mathrm{Z}=4$. The torsion angle between $\mathrm{C}(4)-\mathrm{C}(7)-\mathrm{N}(1)-\mathrm{C}(9)$ is $178.50(13)^{\circ}$ confirms the Schiff base formation. The $\mathrm{C}(7)-\mathrm{N}(1)$ distance of $1.3114(19) \AA$ is normal double bond value and agrees well with those observed in compounds containing azomethine group. In the Schiff base ligand $\mathrm{C}(7)$ $\mathrm{N}(1)-\mathrm{C}(9)$ bond angle is $128.67(13)^{\circ}$.

Table 5. Selected Bond Distances $(\AA)$ and Bond Angles $\left({ }^{\circ}\right)$ for NMPDHAPI

$\begin{array}{llll}\mathrm{C}(1)-\mathrm{O}(1) & 1.3460(18) & \mathrm{N}(1)-\mathrm{C}(7)-\mathrm{C}(4) & 118.52(13) \\ \mathrm{C}(3)-\mathrm{O}(2) & 1.3068(16) & \mathrm{N}(1)-\mathrm{C}(7)-\mathrm{C}(8) & 119.97(14) \\ \mathrm{C}(7)-\mathrm{N}(1) & 1.3114(19) & \mathrm{C}(10)-\mathrm{C}(9)-\mathrm{N}(1) & 118.42(13) \\ \mathrm{C}(12)-\mathrm{O}(3) & 1.3626(19) & \mathrm{C}(14)-\mathrm{C}(9)-\mathrm{N}(1) & 122.01(14) \\ \mathrm{C}(15)-\mathrm{O}(3) & 1.419(2) & \mathrm{C}(7)-\mathrm{N}(1)-\mathrm{C}(9) & 128.67(13) \\ \mathrm{N}(1)-\mathrm{H}(1 \mathrm{~A}) & 0.956(19) & \mathrm{C}(7)-\mathrm{N}(1)-\mathrm{H}(1 \mathrm{~A}) & 110.7(11) \\ \mathrm{O}(1)-\mathrm{H}(1) & 0.8200 & \mathrm{C}(9)-\mathrm{N}(1)-\mathrm{H}(1 \mathrm{~A}) & 120.6(11)\end{array}$

Table 6. Hydrogen Bonds for NMPDHAPI [A and $^{\circ}$ ]

\begin{tabular}{lcccc}
$\mathrm{D}-\mathrm{H} \ldots \mathrm{A}$ & $\mathrm{d}(\mathrm{D}-\mathrm{H})$ & $\mathrm{d}(\mathrm{H} \ldots \mathrm{A})$ & $\mathrm{d}(\mathrm{D} \ldots \mathrm{A})$ & $<(\mathrm{DHA})$ \\
\hline $\mathrm{C}(11)-\mathrm{H}(11) \ldots \mathrm{O}(2) \# 1$ & 0.93 & 2.55 & $3.4578(19)$ & 164.9 \\
$\mathrm{O}(1)-\mathrm{H}(1) \ldots \mathrm{O}(2) \# 2$ & 0.82 & 1.81 & $2.5914(14)$ & 158.4 \\
$\mathrm{~N}(1)-\mathrm{H}(1 \mathrm{~A}) \ldots \mathrm{O}(2)$ & $0.956(19)$ & $1.640(19)$ & $2.5076(16)$ & $148.8(17)$ \\
\hline
\end{tabular}

Symmetry transformations used to generate equivalent atoms:

$\# 1-\mathrm{x}+1,-\mathrm{y},-\mathrm{z} \quad \# 2-\mathrm{x}+1, \mathrm{y}-1 / 2,-\mathrm{z}+1 / 2$

\section{Results and Discussion}

\section{Hirshfeld Surface Analysis}

Hirshfeld surface analysis technique is exploited for the calculation of intermolecular interactions. Hirshfeld surface of the receptors is portrayed in Figure 9 with respect to various properties such as di, de, dnorm, shape index 
and curvedness (Prasad and Meenakshisundaram, 2015a). dnorm surface highlighted two bright red spots indicating the presence of close contacts interms of hydrogen bonding, as well as $\mathrm{O}-\mathrm{H}$ and $\mathrm{H}-\mathrm{O}$ interactions (Prasad and Meenakshisundaram, 2015b). di surfaces exhibited red spots proving the presence of H...O interactions to an extent of $10.0 \%$ in NMPDHAPI and $8.0 \%$ in the case of NMEPDHAPI. de surface showed bright red spots evidencing $\mathrm{O}$...H interactions as dominating ones. The shape index indicated the shape of electron density surface around the molecular interactions. Hirshfield surfaces of individual molecules are given in Figures 9 and 10. The surfaces in the crystal packing clearly indicate the O-H...C and O-H... interactions (Figures 11 and 12).

Figure 9. Hirshfeld Surfaces of NMEPDHAPI a)dnorm b)de c)di d) Curvedness and e) Shape Index

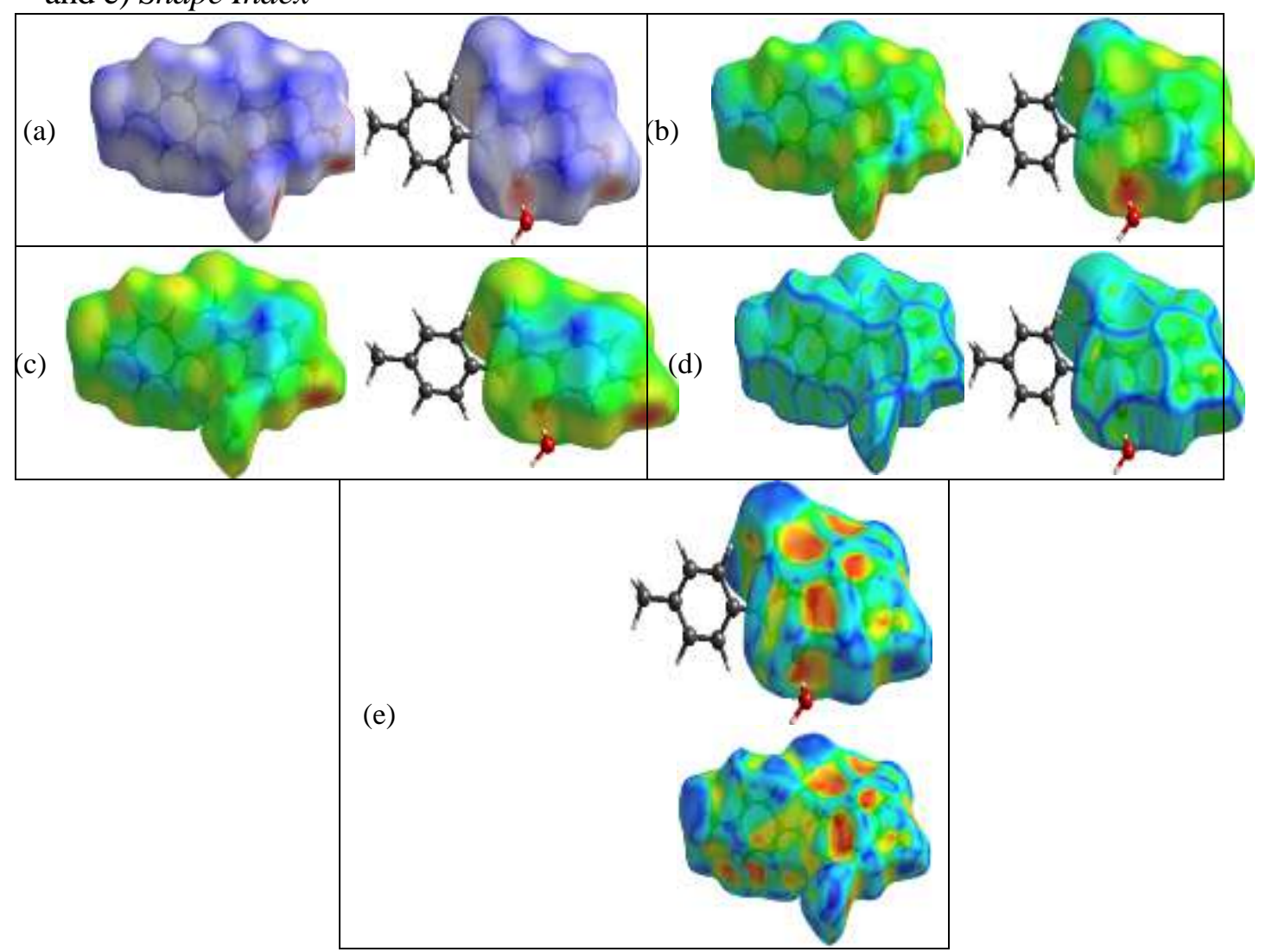


Vol. 5, No. 2 Sambamoorthy et al.: Highly Selective and Sensitive Dual Channel...

Figure 10. Hirshfeld Surfaces of NMPDHAPI a)dnorm b)de c)di d)Curvedness and e)Shape Index
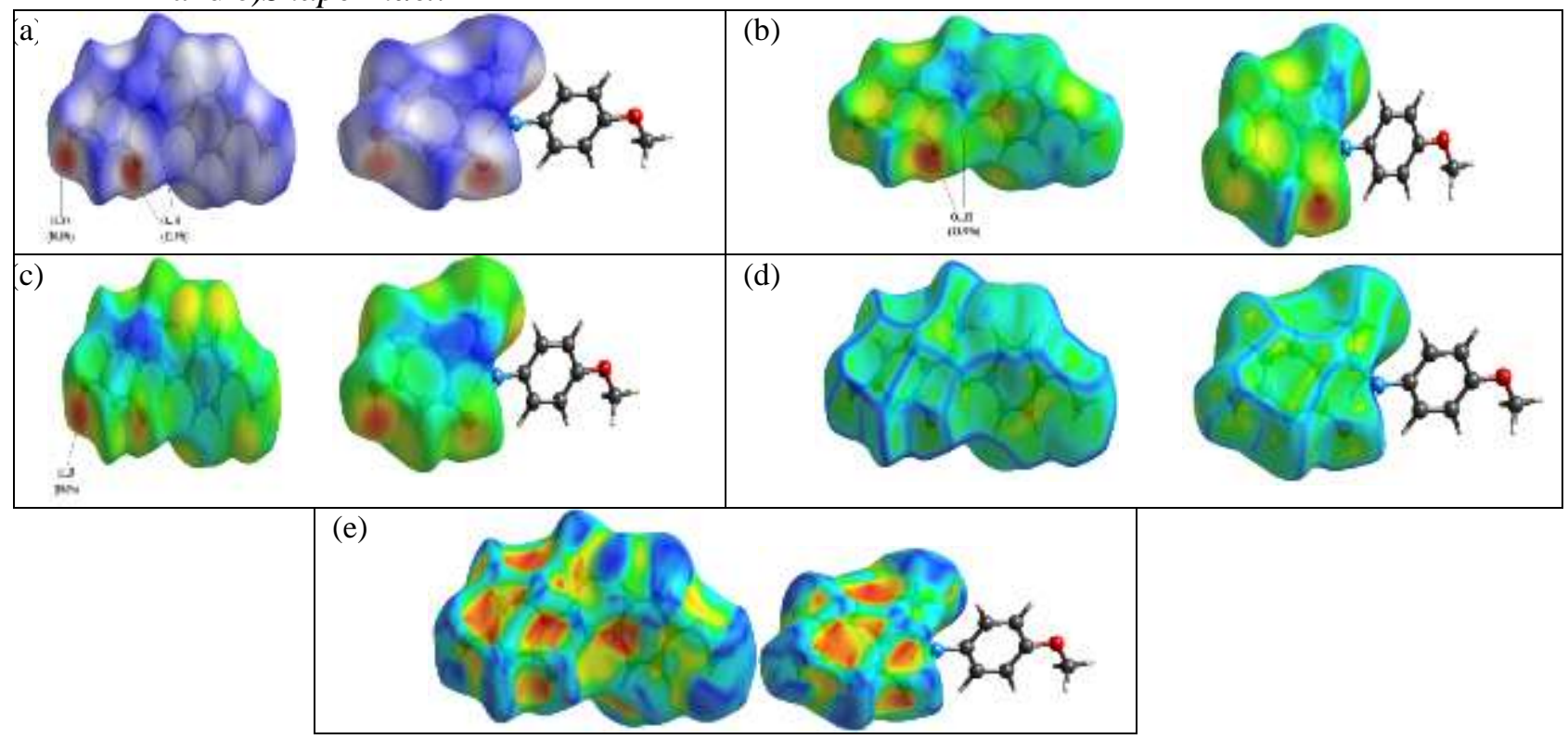

Figure 11.Hirshfeld Surfaces of NMEPDHAPI (a) dnorm in Crystal Packing with H-bond Contacts (b) de Surface in Crystal Packing (c) di Surface in Crystal Packing (d) Curvedness in Crystal Packing and (e) Shape index in Crystal Packing

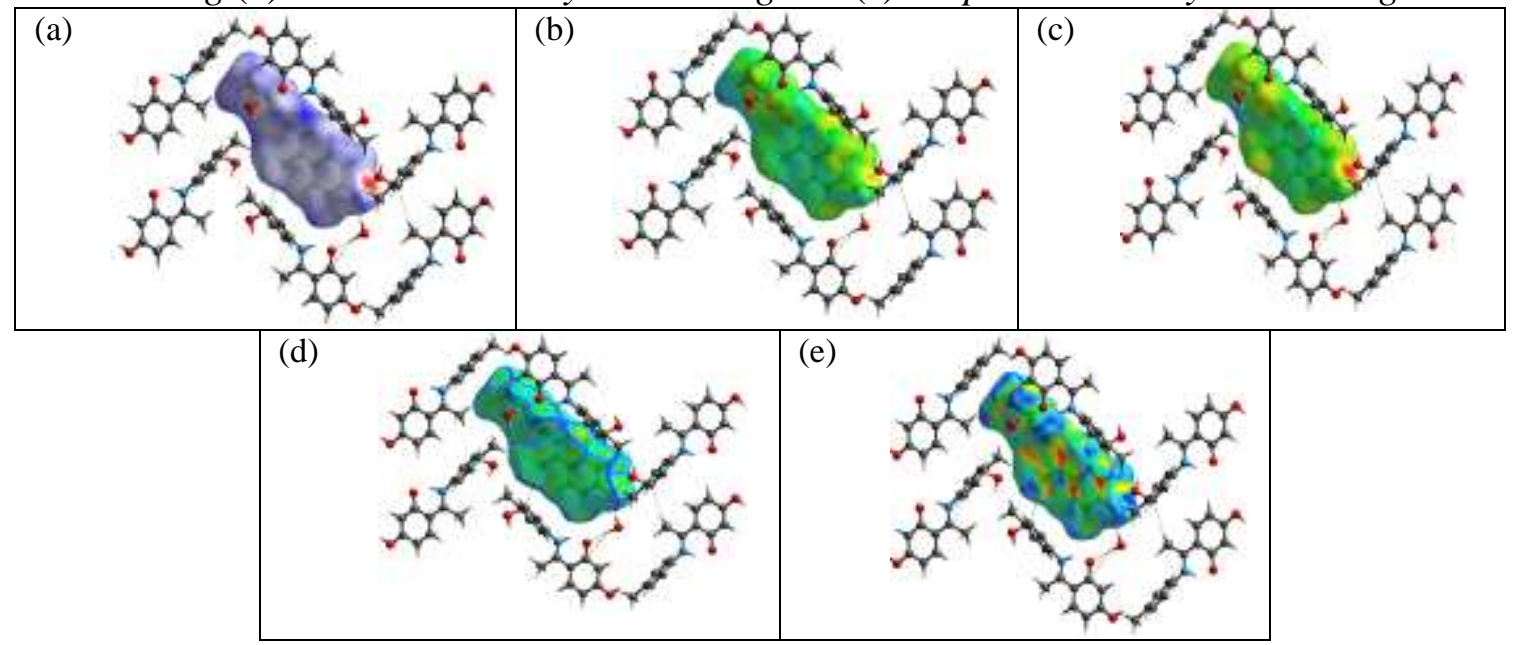


Figure 12.Hirshfeld Surfaces of NMPDHAPI (a) dnorm in Crystal Packing with H-bond Contacts (b) de Surface in Crystal Packing (c) di Surface in Crystal Packing (d) Curvedness in Crystal Packing and(e)Shape Index in Crystal Packing
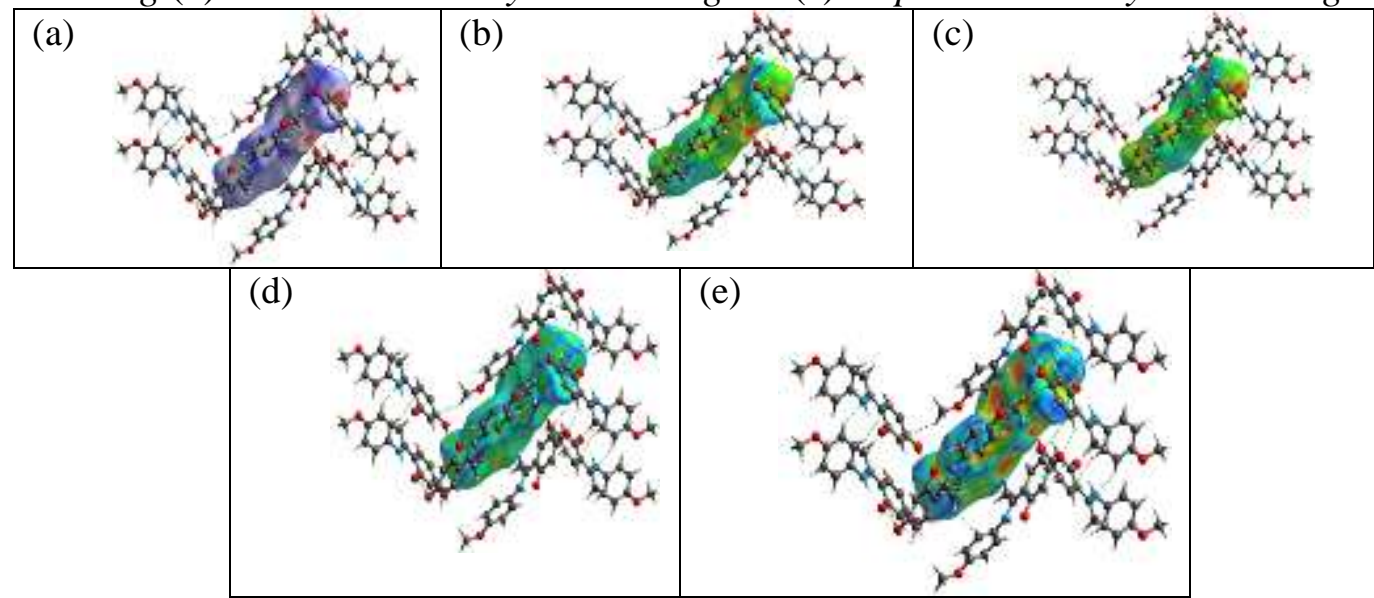

The deformation density of the moleculeis calculated as 0.008 a.u. (maximum) and -0.008 a.u. (minimum) (a.u. is atomic units). A graphical view of the deformation density is shown in Figures 13 and 14. The surfaces are calculated using DFT method with 3-21G as basis set from the crystal data.

Figure 13. Deformation Density Surface of NMEPDHAPI

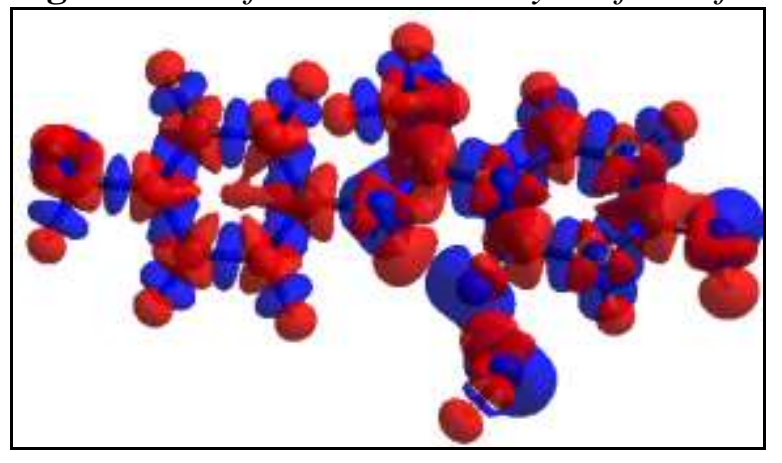

Figure 14. Deformation Density Surface of NMPDHAPI

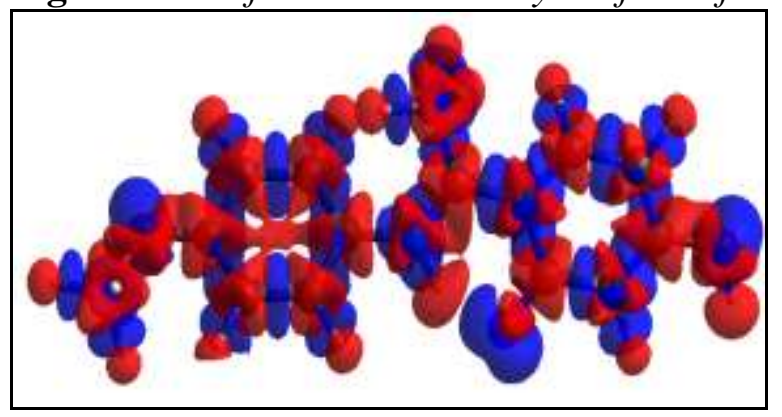


Vol.5, No. 2 Sambamoorthy et al.: Highly Selective and Sensitive Dual Channel...

Fingerprint Analysis

The 2D fingerprint plots of the Schiff base receptors (Figures 15 and 16) summarise the pattern of various intermolecular interactions (Prasad and Meenakshisundaram, 2015a). The O...H interactions and H.... interactions were appearing as spikes in the bottom and top regions. The H....H interactions appeared in the middle region. The H....C and C....H interactions were present in the top left and right corners. The pie chart delineates the percentage contribution of various types of interactions present in the receptor (Figures 17 and 18).

Figure 15.Fingerprint Plots of NMEPDHAPI

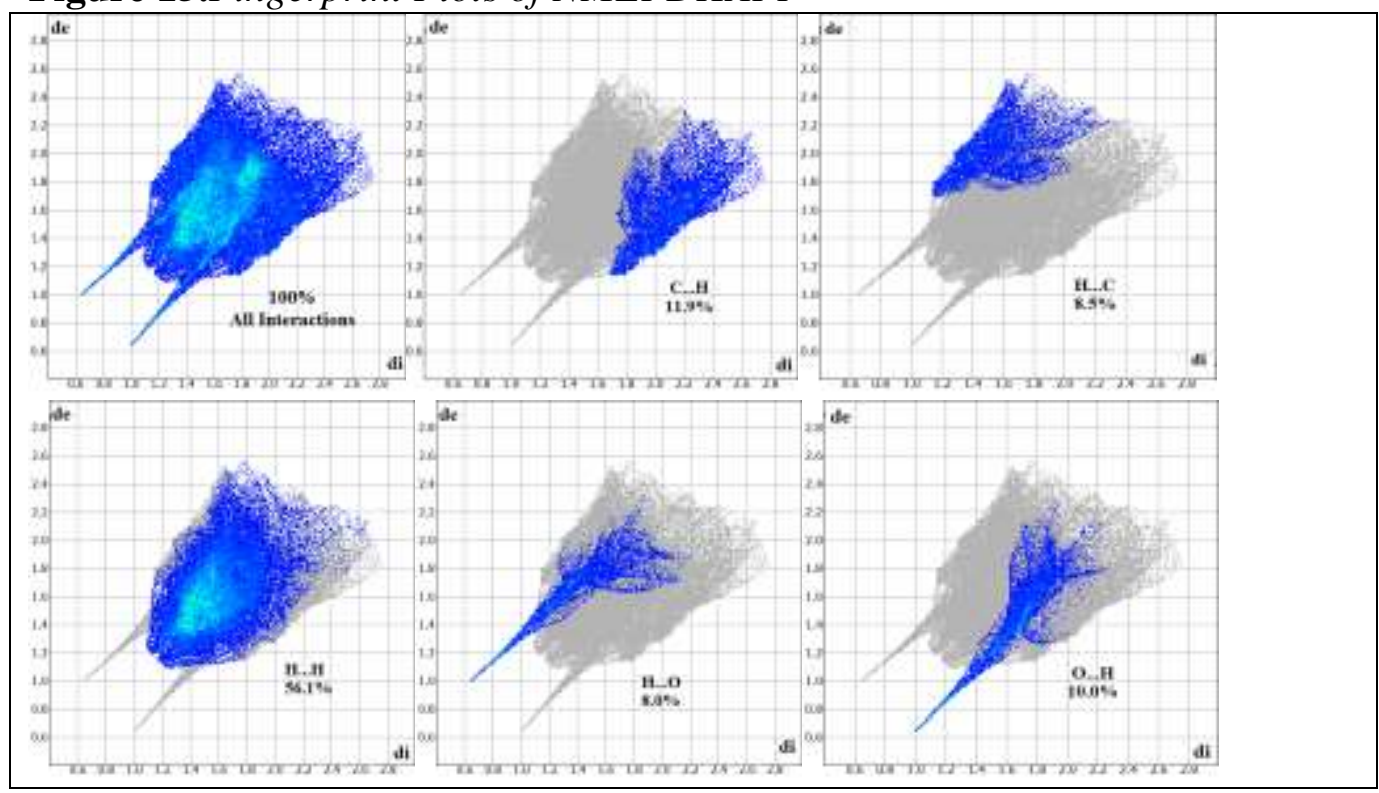

Figure 16. Fingerprint Plots of NMPDHAPI

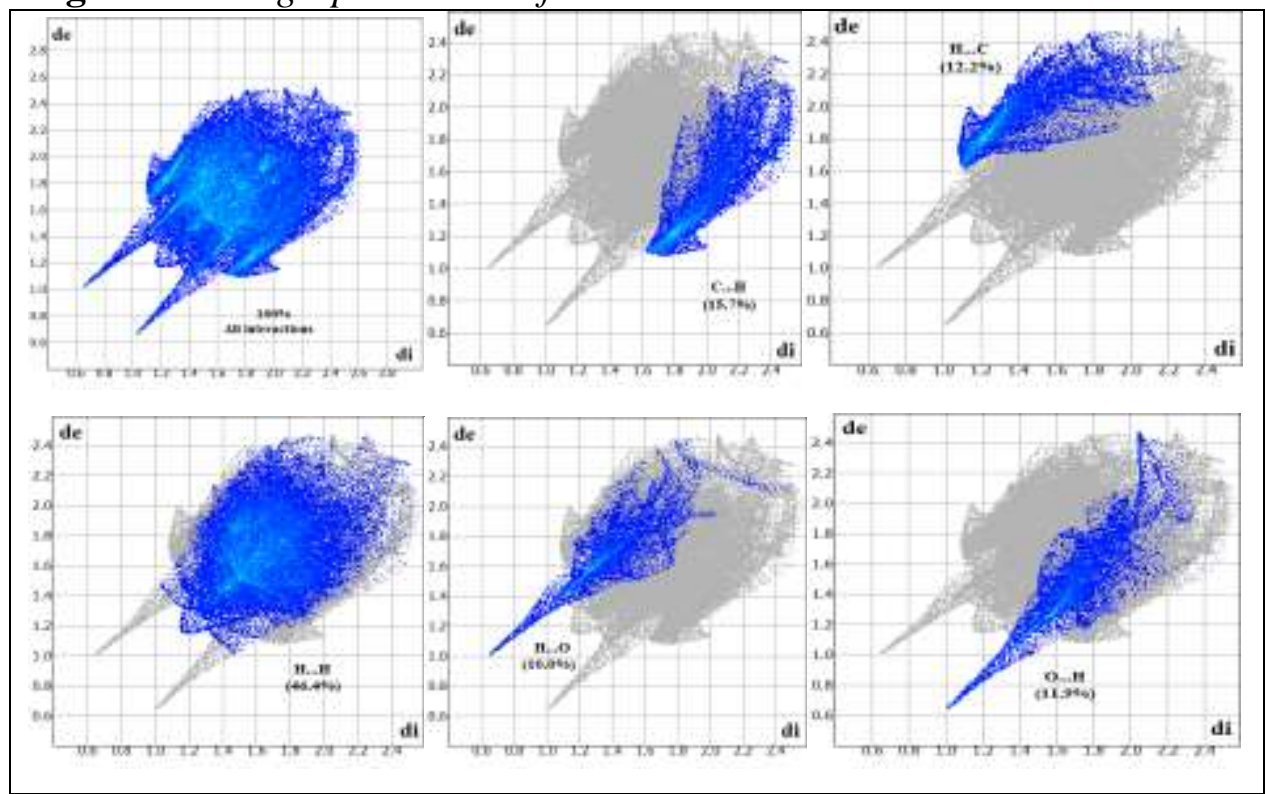


Figure 17. Pie Chart of Molecular Interactions for NMEPDHAPI

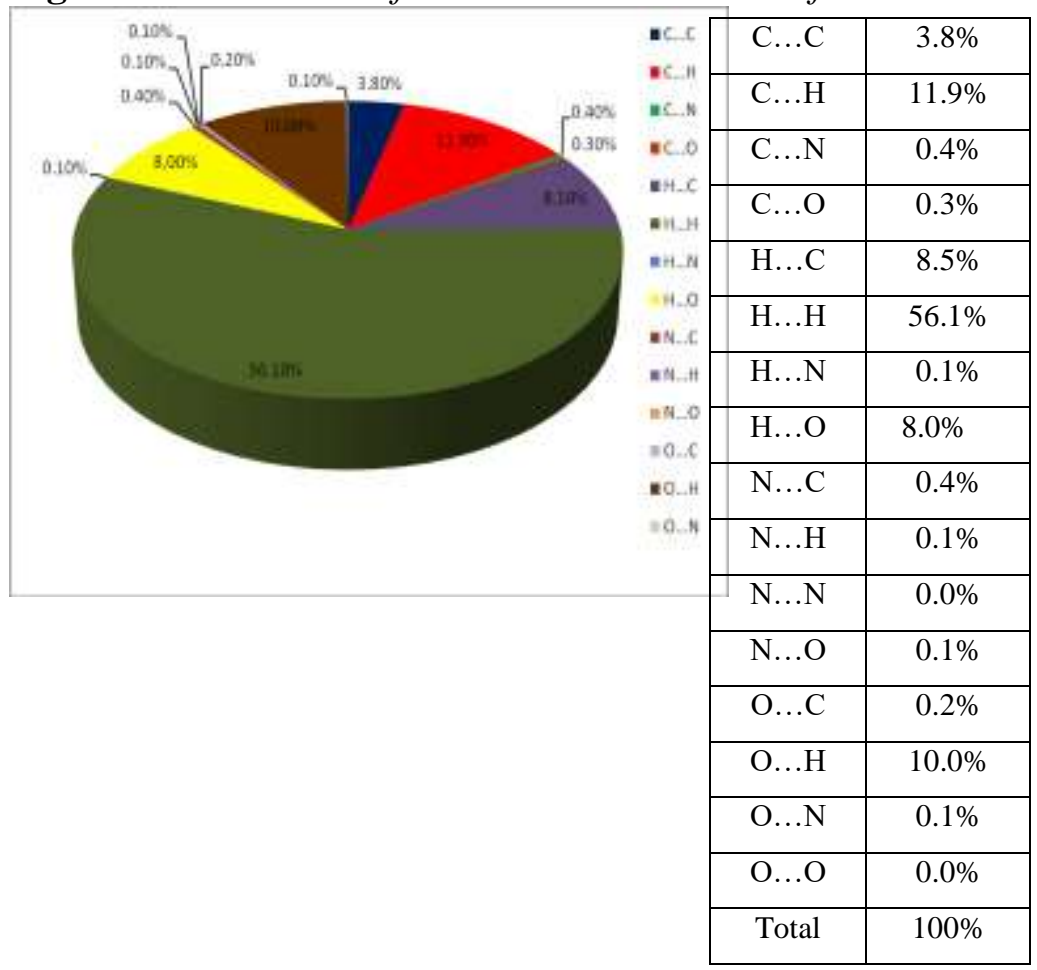

Figure 18. Pie Chart of Molecular Interactions for NMPDHAPI

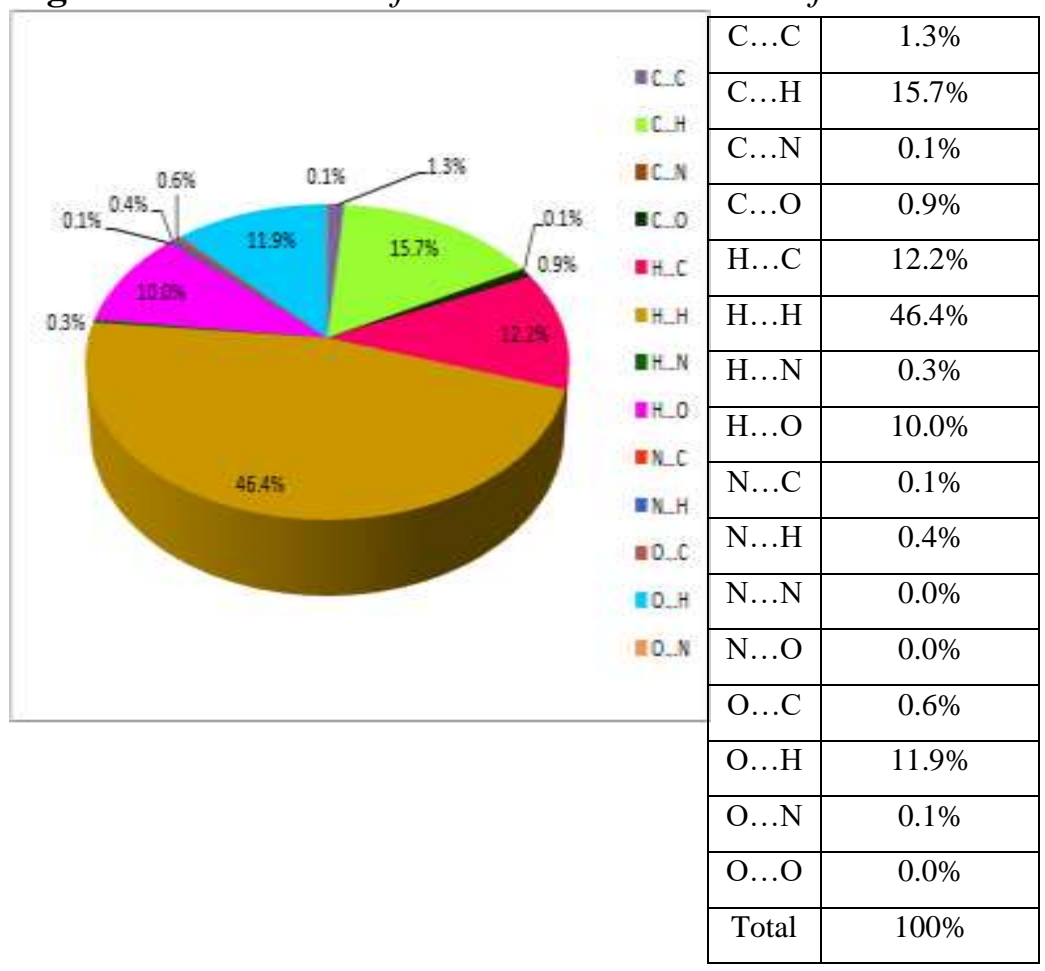




\section{Study of Metal Ion Recognizing Property}

The metal ion recognizing property of the receptors was analysed by UVVisible method and fluorescence method. UV-visible method was performed with the help of SHIMADZU UV spectrophoto meter UV-1800. Fluoresence method was performed with JASCO spectrofluoro photometer FP-8200.

\section{$\underline{\text { Absorption Studies }}$}

To evaluate the sensing ability, receptors $1 \& 2$ were made to interact with two equivalents of various metal ions such as $\mathrm{Na}^{+}, \mathrm{Mg}^{2+}, \mathrm{Ca}^{2+}, \mathrm{Mn}^{2+}, \mathrm{Co}^{2+}$, $\mathrm{Ni}^{2+}, \mathrm{Fe}^{3+,} \mathrm{Cu}^{2+}, \mathrm{Zn}^{2+}, \mathrm{Sr}^{2+}, \mathrm{Cd}^{2+}, \mathrm{Ba}^{2+}, \mathrm{Hg}^{2+}, \mathrm{Pb}^{2+} \& \mathrm{Al}^{3+}$. While receptor 1 had a successful interaction with $\mathrm{Al}^{3+}$ ions, receptor 2 had the same with $\mathrm{Fe}^{3+} \&$ $\mathrm{Cu}^{2+}$ ions. These interactions were evidenced by the emergence of a new peak at $303 \mathrm{~nm}$ in the absorption spectrum of receptor 1 and at $365 \mathrm{~nm} \& 461 \mathrm{~nm}$ in the case of receptor 2 . The synergistic ability was further corroborated by incremental titrations. These changes in the absorption behaviour of the receptors may be imputed to the formation of complexes between the receptors and the metal ions, thus paving the way for LMCT transitions (Prabhu et al., 2012).

The absorption spectrum of receptor 1 exhibits three bands at $228 \mathrm{~nm}\left(\pi-\pi^{*}\right)$, $276 \mathrm{~nm}\left(\pi-\pi^{*}\right)$ and $314 \mathrm{~nm}\left(\mathrm{n}-\pi^{*}\right)$ respectively. Addition of two equivalents of $\mathrm{Al}^{3+}$ ion leads to a bathochromic shit of the band at $315 \mathrm{~nm}$ to an extent of $13 \mathrm{~nm}$. The formation of four isobestic points further confirms the complex formation between the receptor and $\mathrm{Al}^{3+}$ ion.

The above interaction is further proved by performing UV-Visible titrations involving incremental addition of $\mathrm{Al}^{3+}$ solution ( 0.2 equiv. to 2 equiv.) to a solution of receptor. During this titration, the band at $314 \mathrm{~nm}$ in the receptor is red shifted to an extent of $13 \mathrm{~nm}$ and also a hyperchromic effect is observed (Figure 19).

Figure 19. (a) UV-Vis Spectra of Receptor 1 with Different Metals (b) UV-Vis Titration of Receptor 1 with $\mathrm{Al}^{3+}$; Inset: Variation of Absorbance at $303 \mathrm{~nm}$ in the Presence of $\mathrm{Al}^{3+}$

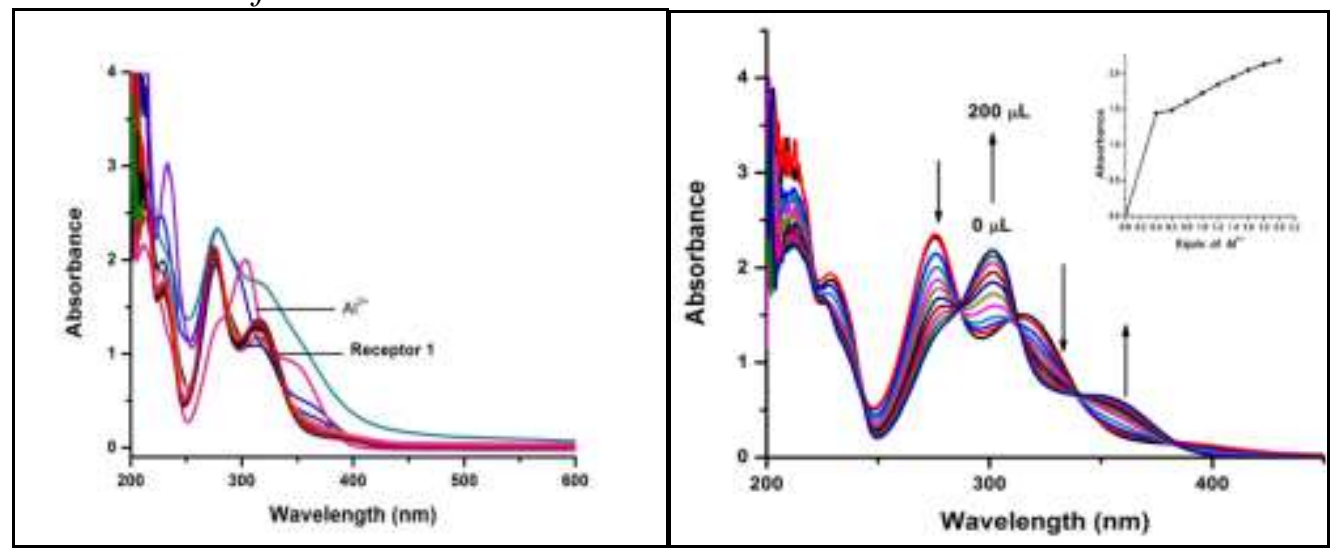

(a)

(b) 
The binding constant of the receptor 1 for $\mathrm{Al}^{3+}$ ion is determined by Benesi-Hildebrand plot as $11.17 \times 10^{3}$ implying strong coordination (Wang et al., 2013).

In the case of receptor 2 , the absorption spectrum has three bands at $229 \mathrm{~nm}(\pi$ $\left.\pi^{*}\right), 273 \mathrm{~nm}\left(\pi-\pi^{*}\right)$ \& $319 \mathrm{~nm}\left(\mathrm{n}-\pi^{*}\right)$. Interaction with $\mathrm{Fe}^{3+} \& \mathrm{Cu}^{2+}$ ions is evidenced by a new band at $365 \mathrm{~nm} \& 461 \mathrm{~nm}$ respectively. This is confirmed by UV-Visible titrations involving $\mathrm{s}$ addition of metal ions (0.2 eqiv. to 2 equiv) independently to a solution of the receptor. The intensity of the bands thus formed increased tremendously (Figure 20). The association constant of the receptor for $\mathrm{Cu}^{2+} \&$ and that for $\mathrm{Fe}^{3+}$ were evaluated as $1.43 \times 10^{2}$ and $1.65 \times 10^{2}$ respectively (Wang et al., 2013).

Figure 20. (a) UV-Vis Spectra of Receptor 2 with Different Metals (b) UV-Vis Titration of Receptor 2 with $\mathrm{Fe}^{3+}$; Inset: Variation of Absorbance at $365.5 \mathrm{~nm}$ in the Presence of $\mathrm{Fe}^{3+}(\mathrm{c}) \mathrm{UV}$-Vis Titration of Receptor 2 with $\mathrm{Cu}^{2+}$; Inset: Variation of Absorbance at $461.5 \mathrm{~nm}$ in the Presence of $\mathrm{Cu}^{2+}$

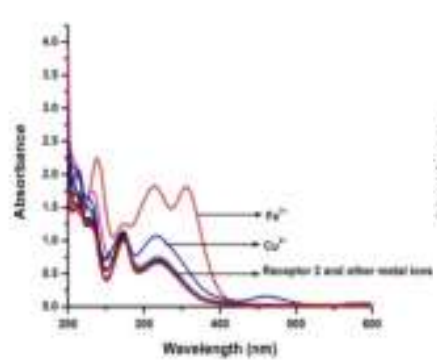

(a)

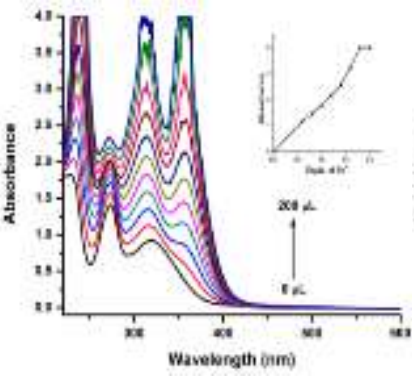

(b)

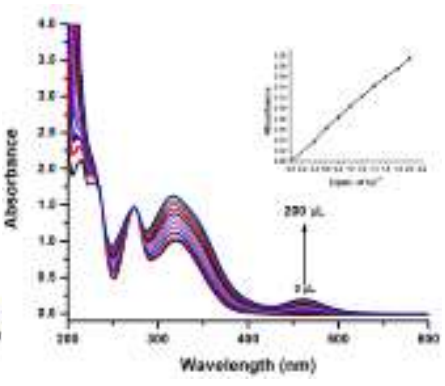

(c)

$\underline{\text { Fluorescence Studies }}$

As done in absorption studies, the two receptors were examined for fluorescence sensing properties with different metal cations. An enormous enhancement of fluorescence intensity of about 117 fold with a substantial blue shift to an extent of $50 \mathrm{~nm}$ was caused during the trapping of $\mathrm{Al}^{3+}$ ion by receptor 1 (Figure 21); whereas a bathochromic shift of $60 \mathrm{~nm} \& 50 \mathrm{~nm}$ was the result of sensing of $\mathrm{Fe}^{3+}$ and $\mathrm{Cu}^{2+}$ ions by receptor 2 . A very small amount of quenching was also observed with receptor 2 (Figure 22). The fluorescence enhancement may be ascribed to the formation of rigid complex chelate system indicating the presence of CHEF effect and the quenching may be probably due to electron or energy transfer process between the metal ion and receptor 2 (Wei et al., 2012).

The binding mode of the receptors with the metal ions was ascertained by incremental addition of 0.2 equiv. to 2 equiv. of the latter to the former. With receptor 1 there was a great enhancement of emission and with receptor 2 quenching was observed.

The presence of other metal, ions did not cause any change in the emission behavior of the receptors. 
Figure 21. (a) Fluorescence Spectra of Receptor 1 with Different Metals (b) Fluorescence Titration of Receptor 1 with $\mathrm{Al}^{3+}$; Inset: Variation of Emission at $446 \mathrm{~nm}$ in the Presence of $A l^{3+}$

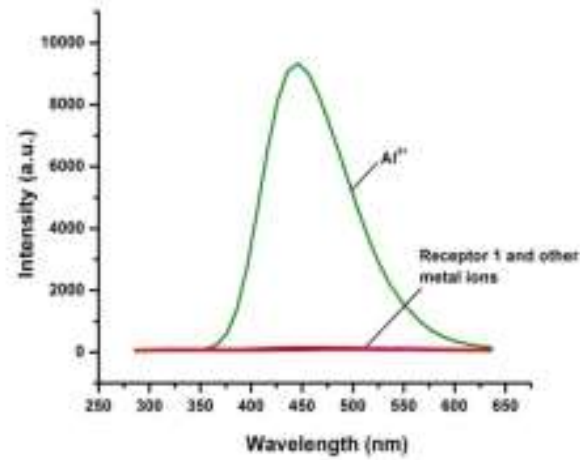

(a)

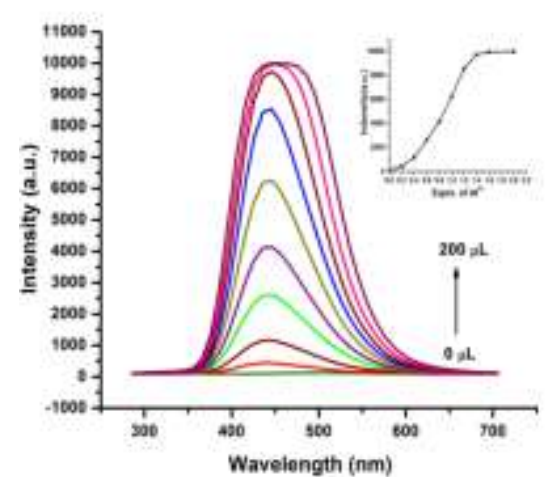

(b)

Figure 22. (a) Fluorescence Spectra of Receptor 2 with Different Metals (b) Fluorescence Titration of Receptor 2 with $\mathrm{Fe}^{3+}$; Inset: Variation of Emission at $434 \mathrm{~nm}$ in the Presence of $\mathrm{Fe}^{3+}$ (c) Fluorescence Titration of Receptor 2 with $\mathrm{Cu}^{2+}$ Inset: Variation of Emission at $424 \mathrm{~nm}$ in the Presence of $\mathrm{Cu}^{2+}$

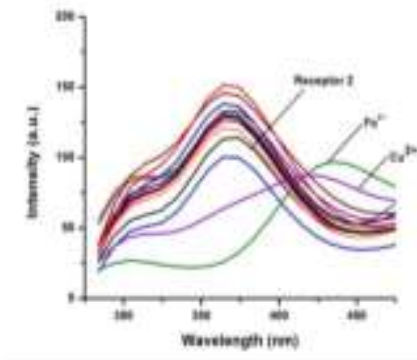

(a)

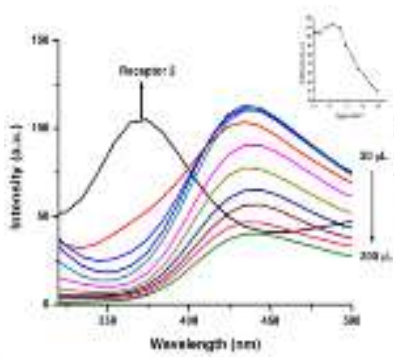

(b)

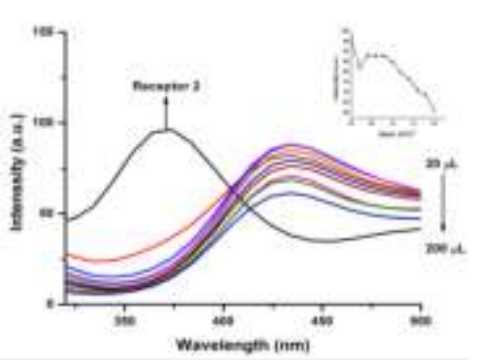

(c)

$\underline{\text { Selectivity and Competitive Studies }}$

In order to investigate the selectivity of the receptors, their sensing behaviour was examined in the presence of other metal ions. It is clear that no interference was caused by other metal ions for the detection of $\mathrm{Cu}^{2+}$ and $\mathrm{Fe}^{3+}$ ions, while a small amount of interference by $\mathrm{Mg}^{2+}$ and $\mathrm{Pb}^{2+}$ was noticed for the detection of $\mathrm{Al}^{3+}$ ion (Hosseini et al., 2010) (Figures 23 and 24). 
Figure 23. Fluorescence Titration of Receptor 1 with $A l^{3+}$ in Presence of All Other Metal Ions

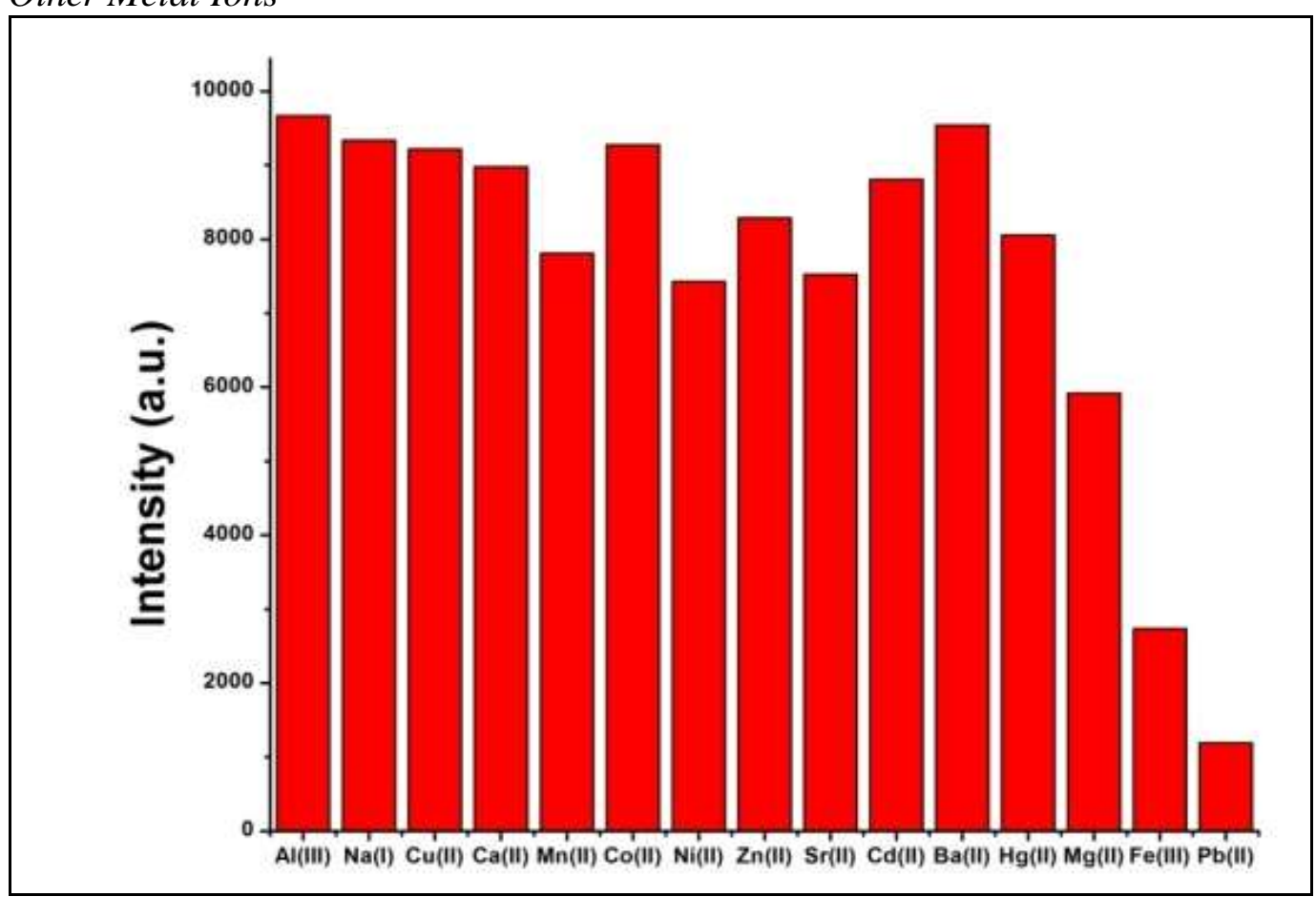

Figure 24. (a) Fluorescence Titration of Receptor 2 with $\mathrm{Fe}^{3+}$ in Presence of All Other Metal Ions b) Fluorescence Titration of Receptor 2 with $\mathrm{Cu}^{2+}$ in Presence of All Other Metal Ions

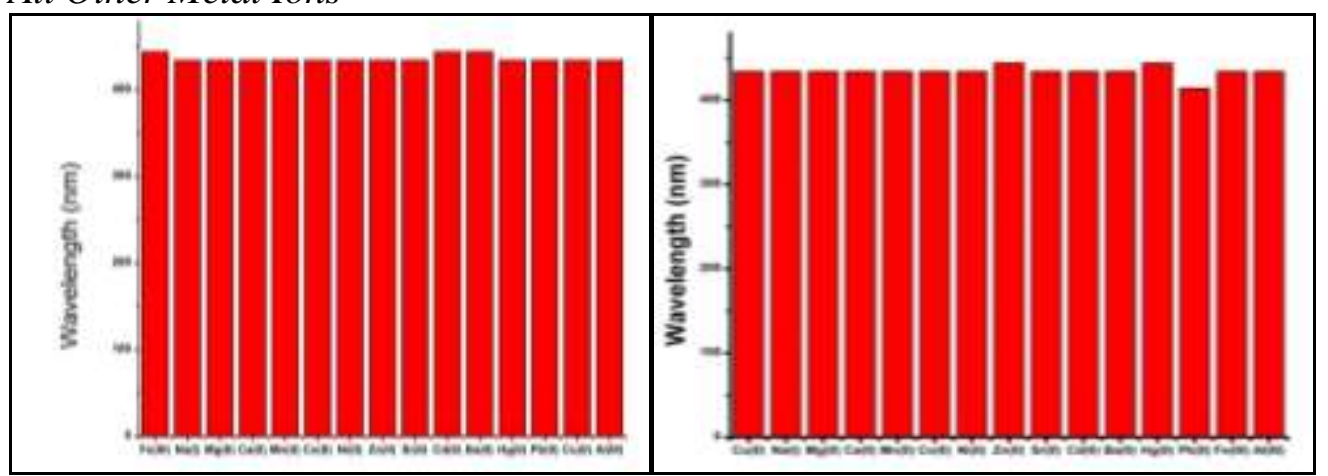

(a)

(b)

$\underline{\text { Stoichiometry, Detection Limit and Reversibility }}$

Jobs plot studies reveal that the stoichiometry of the complex formed by receptor 1 with $\mathrm{Al}^{3+}$ ion and that of receptor 2 with $\mathrm{Cu}^{2+} \& \mathrm{Fe}^{3+}$ ions were 2:1 The detection limit for $\mathrm{Al}^{3+}$ was $6.532 \times 10^{-9} \mathrm{M}$ and that for $\mathrm{Cu}^{2+} \& \mathrm{Fe}^{3+}$ were $4.086 \times 10^{-6} \mathrm{M} \& 1.265 \times 10^{-6} \mathrm{M}$ respectively (Wang et al., 2010b).

The reversibility of the recognition process of receptors was evaluated by adding $\mathrm{Na}_{2}$ EDTA to a mixture of receptor and $\mathrm{Al}^{3+} / \mathrm{Cu}^{2+} / \mathrm{Fe}^{3+}$ Reappearance 
Vol. 5, No. 2 Sambamoorthy et al.: Highly Selective and Sensitive Dual Channel...

of the free receptors' emission pattern proved the reversible nature of sensing ability of the receptors (Gupta et al., 2014) (Figures 25 and 26).

Figure 25. Fluorescence Spectrum of Receptor 1 with $\mathrm{Al}^{3+}$ and $\mathrm{Na}_{2} \mathrm{EDTA}$

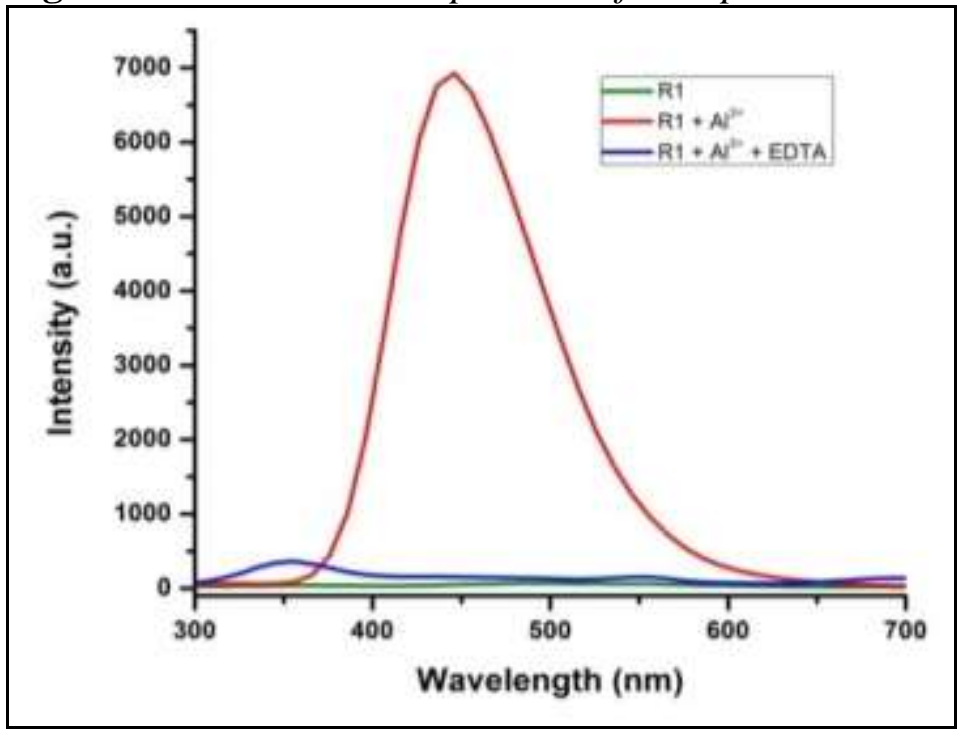

Figure 26. (a) Fluorescence Spectrum of Receptor 2 with $\mathrm{Fe}^{3+}$ and $\mathrm{Na}_{2} \mathrm{EDTAb}$ ) Fluorescence Spectrum of Receptor 2 with $\mathrm{Cu}^{2+}$ and $\mathrm{Na}_{2}$ EDTA

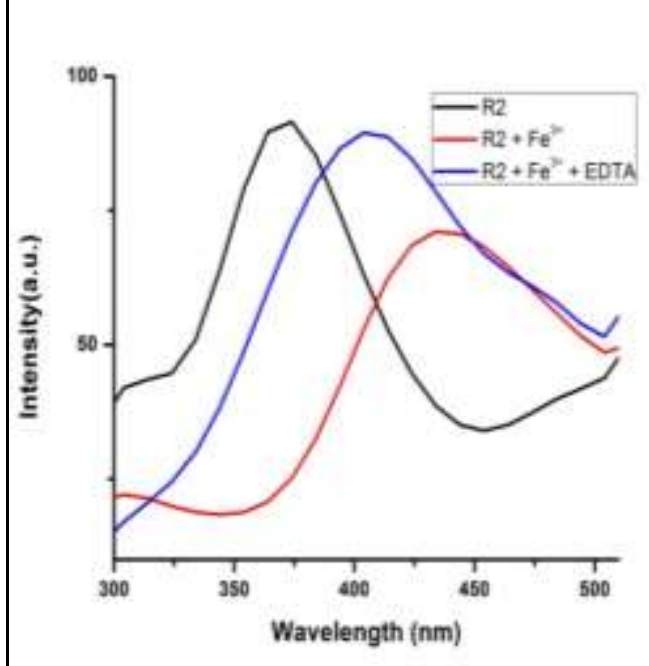

(a)

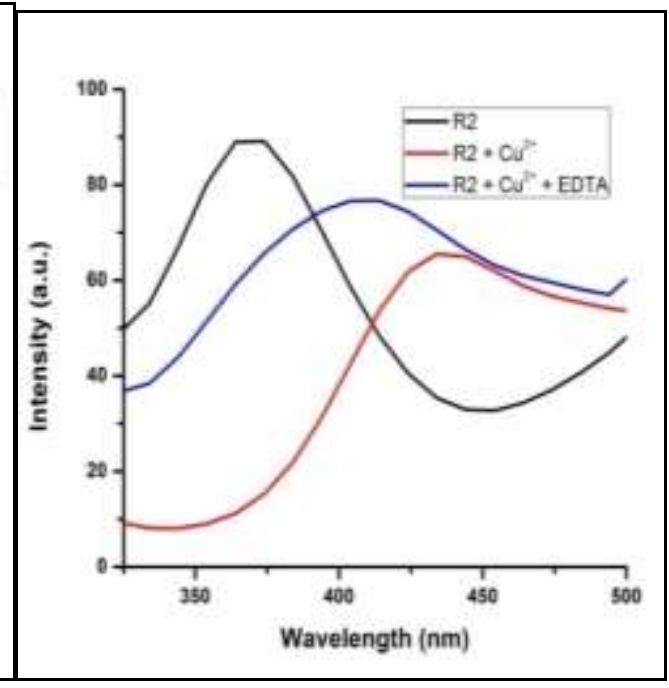

(b)

\section{$\underline{\text { IR Titration }}$}

In the IR spectra of receptor 1 the band due to azomethine group appears at $1639 \mathrm{~cm}^{-1}$, which is shifted to $1573 \mathrm{~cm}^{-1}$ that is to an extent of $66 \mathrm{~cm}^{-1}$ during the addition of $\mathrm{Al}^{3+}$. The new bands at $404 \mathrm{~cm}^{-1}$ and $622 \mathrm{~cm}^{-1}$ are due to the M$\mathrm{N}$ and $\mathrm{M}-\mathrm{O}$ bonds confirming the coordination of receptor with $\mathrm{Al}^{3+}$ ion (Figure 27). 
Figure 27. (a) IR Spectra of Receptor 1 b) IR Spectra of Receptor $1+A l^{3+}$
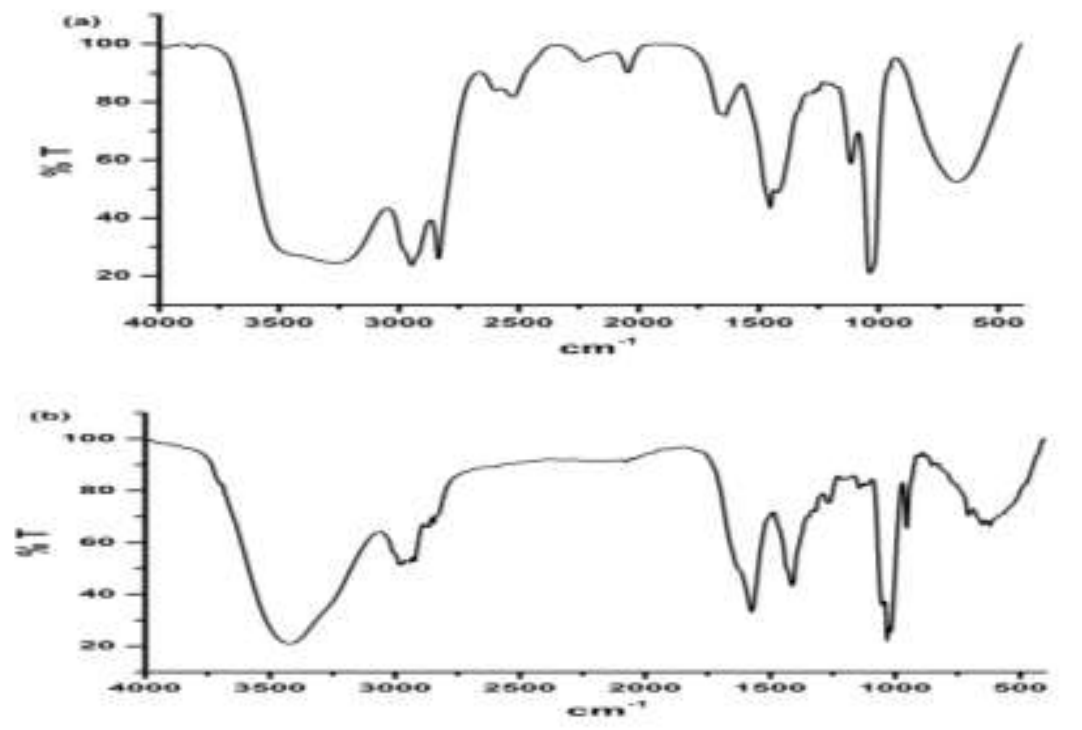

During IR titration receptor 2 shows a shift of the order of $1 \mathrm{~cm}^{-1}$ in the band due to $\mathrm{C}=\mathrm{N}$ bond confirming the coordination with $\mathrm{Cu}^{2+}$ ion through nitrogen atom of azomethine group. This is further confirmed by the appearance of new bands at $414 \mathrm{~cm}^{-1}(\mathrm{M}-\mathrm{N})$ and $619 \mathrm{~cm}^{-1}(\mathrm{M}-\mathrm{O})$ (Figure 28).

Figure 28. (a) IR Spectra of Receptor 2 b) IR Spectra of Receptor $2+C u^{2+}$
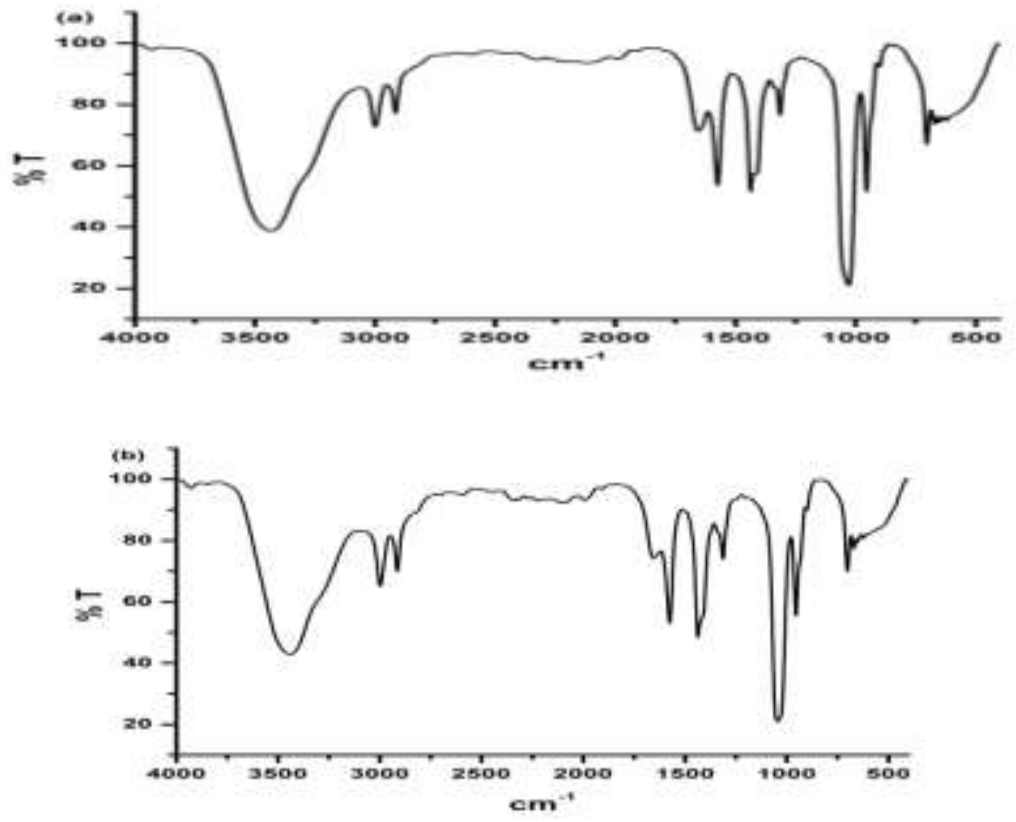


\section{$\underline{\text { CV Titration }}$}

The coordination of receptors with the metal ions was further evidenced by cyclic voltammetry studies. In the cyclic voltammogram of receptor 1 exhibits one oxidation peak $\left(\mathrm{E}_{\mathrm{ox}}=-0.507 \mathrm{~V}\right)$ and one reduction peak $\left(\mathrm{E}_{\mathrm{red}}=-0.698 \mathrm{~V}\right)$. The addition of 2 equivalent of $\mathrm{Al}^{3+}$ changes the oxidation peak to $-0.438 \mathrm{~V}$ and the reduction peak to $-1.155 \mathrm{~V}$. There is also considerable change in the $\Delta \mathrm{E}$ value of the order of $0.774 \mathrm{~V}$ from 1.206V (Figure 29).

Figure 29. Cyclic Voltammogram of Receptor 1 with $\mathrm{Al}^{3+}$

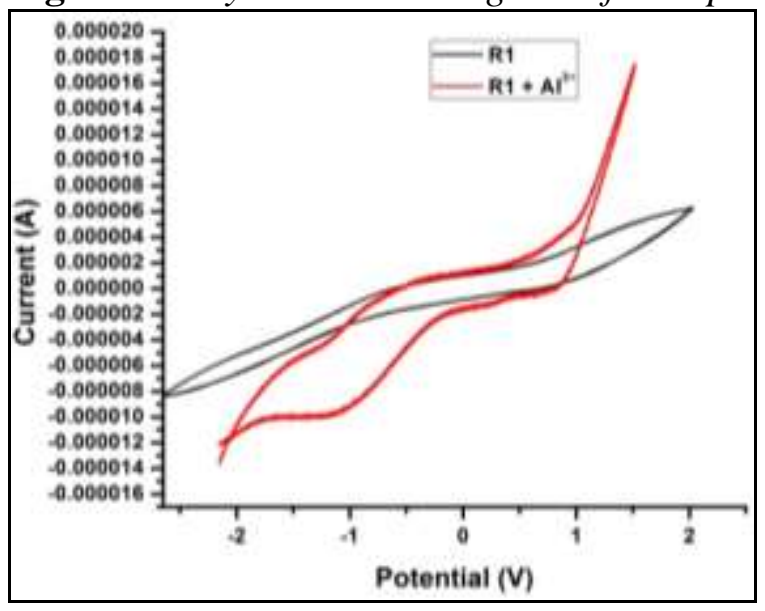

In the case of receptor 2 one oxidation peak $\left(E_{o x}=-0.708\right)$ and one reduction peak $\left(E_{\text {red }}=+0.684 \mathrm{~V}\right)$ are observed. The addition of 2 equivalent of $\mathrm{Fe}^{3+}$ altered the oxidation peak at $\mathrm{E}_{\mathrm{ox}}=0.282 \mathrm{~V}$ and $\mathrm{E}_{\text {red }}$ value is changed to $-1.451 \mathrm{~V}$. On the other hand the addition of 2 equivalent of $\mathrm{Cu}^{2+}$ shows three oxidation peaks and corresponding reduction peaks. The $\Delta \mathrm{E}$ value is also changed after the addition of $\mathrm{Fe}^{3+}$ and $\mathrm{Cu}^{2+}$. These observations provide additional evidence for the complex formation (Figure 30).

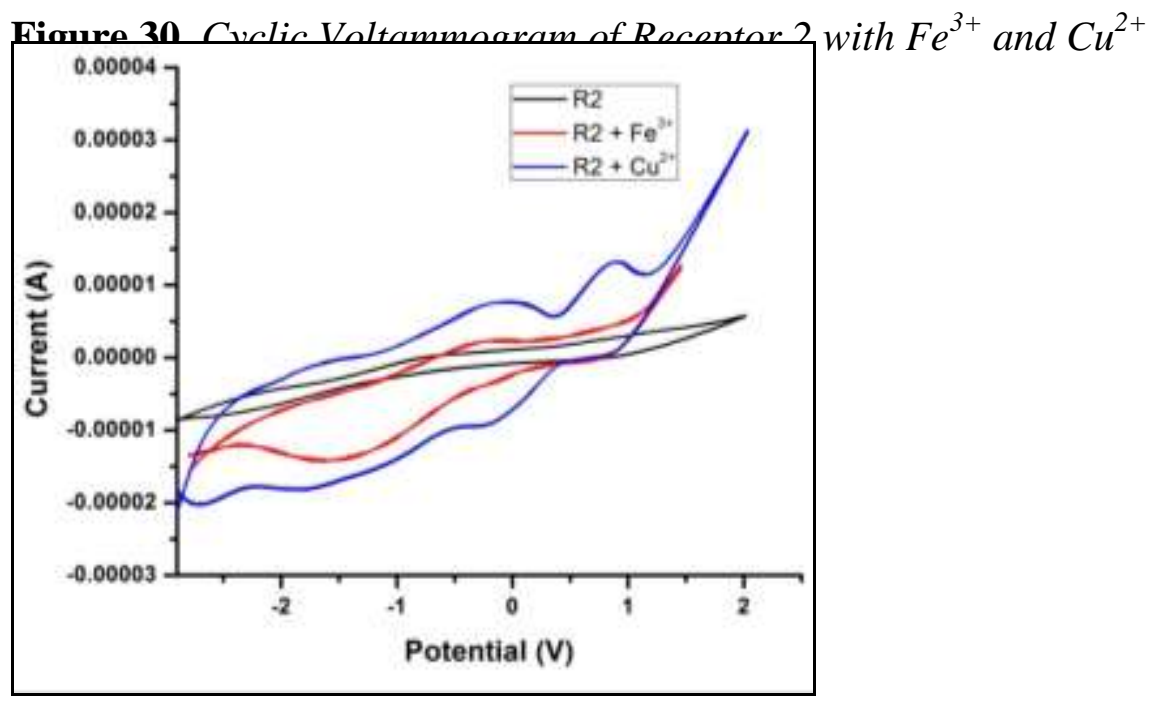




\section{Conclusions}

Two novel Schiff bases, N-4-methylphenyl(2,4-dihydroxyacetophenylideneimine) and N-4-methoxyphenyl(2,4-dihydroxyacetophenylideneimine) have been synthesized. The structure of receptors has been confirmed from the Singlecrystal X-ray diffraction technique. The intermolecular interactions are visualized by a Hirshfeld surface analysis. Fingerprint plots confirm the quantity of interactions present in the receptor molecules. The Schiff base NMEPDHAPI acts as a chemosensor selectively for $\mathrm{Al}^{3+}$ ion and the Schiff base NMPDHAPI acts as a chemosensor for $\mathrm{Fe}^{3+}$ and $\mathrm{Cu}^{2+}$ ions over a number of other metal ions such as $\mathrm{Na}^{+}, \mathrm{Mg}^{2+}, \mathrm{Ca}^{2+}, \mathrm{Mn}^{2+}, \mathrm{Co}^{2+}, \mathrm{Ni}^{2+}, \mathrm{Zn}^{2+}, \mathrm{Sr}^{2+}, \mathrm{Cd}^{2+}, \mathrm{Ba}^{2+}, \mathrm{Hg}^{2+}$ and $\mathrm{Pb}^{2+}$. The sensing property of the receptors is assessed by UV-Vis and fluorescence methods. The stoichiometry ratio of the receptors with $\mathrm{Al}^{3+}$, $\mathrm{Fe}^{3+}$ and $\mathrm{Cu}^{2+}$ is found to be $2: 1$ by Job's plot. The recognizing efficiency of the receptor is found to be reversible. It can be concluded that Schiff base receptors prepared from commonly available reagents could act as cost effective, selective, sensitive and reversible sensors for $\mathrm{Al}^{3+}, \mathrm{Fe}^{3+} \& \mathrm{Cu}^{2+}$ ion over many other metal ions. The sensing ability of the synthesized Schiff bases can be further utilized for the construction of logic gates and also in bio imaging technique. Many similar Schiff bases are being synthesized by the authors in their parent department laboratory and their metal ion/anion sensing property is also being studied. The authors also planned to apply their findings in the field of bio imaging.

\section{Acknowledgments}

The authors are thankful to the Director, SAIF, IIT Madras, Chennai for providing analytical support. The authors wish to express their thanks to the Secretary, Principal, Vice-Principal and faculty members of Department of Chemistry, Seethalakshmi Ramaswami College, Tiruchirappalli, Tamil Nadu for providing laboratory facilities and support. The authors also express their thanks to ATINER, Greece.

\section{References}

Aazam, E. S., Fawazy, A, and Hitchcock, P. B. 2006.4-methyl-7-(salicylideneamino) coumarin. ActaCryst.E62 (2006) o4285-04287.

Aazam, E. S. 2010. Synthesis and characterization of mononuclear and binuclear metal complexes of a new fluorescent dye derived from 2-Hydroxy-1-naphthaldehyde and 7-amino-4-methyl coumarin. JKAU: Sci. 22 (2010) 101-116.

An, J. M., Yang, Z. Y., Yan, M. H., and Li, T. R. 2013. A Novel off-on fluorescence Chemosensor for $\mathrm{Ca}^{2+}$ based on Rhodamine-Coumarin Schiff base derivative. Journal of Luminescence 139 (2013) 79-83. 
Chang, Y. J., Hung, P. J., Wan, C. F., and Wu, A. T. 2014. A highly selective fluorescence turn-on and reversible sensor for $\mathrm{Al}^{3+}$ ion. Inorganic Chemistry Communications 39 (2014) 122-125.

Fan, L., Li, T. R., Wang, B. D., Yang, Z. Y., and Liu, C. J. 2014. A colorimetric and turn-on fluorescent chemosensor for $\mathrm{Al}(\mathrm{III})$ basedon a chromone Schiff-base. Spectrochimica Acta Part A: Molecular and Biomolecular Spectroscopy 118 (2014) 760-764.

Gupta, V. K., Singh, A. K., and Kumawat, L. K. 2014.Thiazole Schiff base turn-on fluorescent chemosensor for $\mathrm{Al}^{3+}$ ion. Sensors and Actuators B: Chemical 195 (2014) 98-108.

Hosseini, M., Vaezi, Z., Ganjali, M. R., Faridbod, F., Abkenar, S. D., Alizadeh, K., and Salavati-Niasari, M. 2010. Fluorescence "turn on" chemosensor for the selective detection of zinc ion based Schiff-base derivative. SpectrochimicaActa Part A 75 (2010) 978-982.

Hsieh, W. H., Wan, C. F., Liao, D. J., and Wu, A. T. 2012. A turn on Schiff base fluorescence sensor for zinc ion Tetrahdedron letters 53 (2012) 5848-5851.

Issa, R. M., Khedr, A. M., and Rizk, H. 2008. ${ }^{1}$ H NMR, IR and UV/VIS spectroscopic studies of some Schiff bases derived from 2-Aminobenzothiazole and 2-Amino3-hydroxypyridine. Journal of the Chinese Chemical Society 55 (2008) 875-884.

Kemp, W. 2009.Organic Spectroscopy. Palgrave, New York.

Keyes, T. E., Evrard, B., Vos, J. G., Johannes, G., Brady, C., McGarvey, J. J., and Jayaweera, P. 2004. Electronic and photophysical properties of novel phenol bound dinuclear ruthenium complex: evidence for a luminescent mixed valence state. Dalton Trans. 15 (2004) 2341-2346.

Kim, S., Young Noh, J., Young, K., JinHoon Kim, K., Kyung Kang, H., Nam, S. W., Kim, S. H., Park, S. Kim, C., and Kim, J. 2012. Salicylimine-Based Fluorescent Chemosensor for Aluminum Ions and Application to Bioimaging.Inorg. Chem. 51 (2012) 3597-3602.

Lashanizadegan, M. and Seraj. S. 2010. Synthesis and Characterization of non-symmetric tetradentate complexes of $\mathrm{Zn}(\mathrm{II}), \mathrm{Co}(\mathrm{II})$, and Cu(II). Turk. J. Chem. 34 (2010) 263268.

Prabhu, S., Saravanamoorthy, S., Ashok, M., and Velmathi, S. 2012 Colorimetric and fluorescent sensing of multi metal ions and anions by salicylaldimine based receptors. Journal of Luminescence 132 (2012) 979-986.

Prasad, A. A., and Meenakshisundaram, S. P. 2015a.Crystal growth, characterization and Density functional theorycomputations of supramolecular N-carbamothioylacetamide. Cryst. Res. Technol. 50(5) (2015) 395-404.

Prasad, A. A., and Meenakshisundaram, S. P. 2015b. Hydrogen-bonded supramolecular architecture in nonlinear optical ammonium 2,4-Dinitrophenolate hydrate.J. Appl. Cryst. 48 (2015) 844-852.

Sahoo, S. K., Sharma, D., Bothra, S., Mondal Roy, S., Kumar, R., Kumar, A. S. K., Nandre, J. P., Patil, U. D., and Callan, J. F. 2016. Pyridoxal derivedchemosensor: Its application in anion sensing and molecular logic gate building. Indian Journal of Chemistry 55A (2016) 44-50.

Santhi, S., Sandhiya, S., Ramya, R., and Amala, S. 2014. Synthesis Characterization and Biological Studies on N,N'-Ethylenebis-(2,4-Dihydroxyacetophenylideneimine) and its Complexes with $\mathrm{Mn}(\mathrm{II}), \mathrm{Co}(\mathrm{II}), \mathrm{Ni}(\mathrm{II})$ and $\mathrm{Cu}(\mathrm{II})$. The international journal of science and technoledge, 2 (2014) 102-106.

Selvameena, R., Santhi, S., Anusha, D., and Amala, S. 2014. Synthesis, Characterization and Biological Studies of N,N'-Bis(2-Hydroxynaphthalidene)-4-Ethylphenyl 
Methanediamine and its Complexes with $\mathrm{Co}(\mathrm{II}), \mathrm{Ni}(\mathrm{II})$ and $\mathrm{Cu}(\mathrm{II})$. The international journal of science and technoledge, 2 (2014) 107-112.

Shrivastava, S. 2012.Combined effect of HEDTA and selenium against aluminum induced oxidative stress in rat brain. J Trace Elem Med Biol. 26 (2012) 210-214.

Wang, S., Men, G., Zhao, L., Hou, Q., and Jian, S. 2010a.Binaphthyl-derived salicylidene Schiff base for dual-channel sensing of $\mathrm{Cu}$, Zncations and integrated molecular logic gates. Sensors and Actuators B 145 (2010) 826-831.

Wang, L., Qin, W., Tang, X., Dou, W., Liu, W., Teng, Q., and Yao, X. 2010b. A Selective, Cell-Permeable Fluorescent Probe for Al3+ in Living Cells.Org. Biomol. Chem. 8 (2010) 3751-3757.

Wang, L., Li, H. and Cao, D. 2013.A new photoresponsivecoumarin-derived Schiff base: Chemosensor selectivelyfor $\mathrm{Al}^{3+}$ and $\mathrm{Fe}^{3+}$ and fluorescence "turn-on" under room light. Sensors and Actuators B 181 (2013) 749-755.

Yang, L., Zhu, W., Fang, M., Zhang, Q., and Li, C. 2013.A new carbazole-based Schiff-base as fluorescent chemosensor for selective detection of $\mathrm{Fe}^{3+}$ and $\mathrm{Cu}^{2+}$. Spectrochimica Acta Part A: Molecular and Biomolecular Spectroscopy 109 (2013) 186-192. 
